\title{
An integrated study of uranyl mineral dissolution processes Etch pit formation, effects of cations in solution, and secondary precipitation
}

\author{
Journal Article \\ Author(s): \\ Schindler, M.; Hawthorne, F.C.; Mandaliev, P.; Burns, P.C.; Maurice, P.A. \\ Publication date: \\ 2011-02 \\ Permanent link: \\ https://doi.org/10.3929/ethz-b-000031352 \\ Rights / license: \\ In Copyright - Non-Commercial Use Permitted \\ Originally published in: \\ Radiochimica acta 99(2), https://doi.org/10.1524/ract.2011.1802
}




\title{
An integrated study of uranyl mineral dissolution processes: etch pit formation, effects of cations in solution, and secondary precipitation
}

\author{
By M. Schindler ${ }^{1} *$, F. C. Hawthorne ${ }^{2}$, P. Mandaliev ${ }^{3}$, P. C. Burns ${ }^{4}$ and P. A. Maurice ${ }^{4}$ \\ ${ }^{1}$ Department of Earth Sciences. Laurentian University, Sudbury, ON, Canada \\ 2 Department of Geological Sciences, University of Manitoba, Winnipeg, MB, Canada \\ ${ }^{3}$ Department of Environmental Sciences, ETH Zürich, Zürich, Switzerland \\ ${ }^{4}$ Department of Civil Engineering and Geological Sciences, University of Notre Dame, Notre Dame, IN, USA
}

(Received January 12, 2010; accepted in revised form July 15, 2010)

\section{Uranyl minerals / Dissolution / Coatings / Environment / AFM / XPS}

Summary. Understanding the mechanism(s) of uraniummineral dissolution is crucial for predictive modeling of $\mathrm{U}$ mobility in the subsurface. In order to understand how $\mathrm{pH}$ and type of cation in solution may affect dissolution, experiments were performed on mainly single crystals of curite, $\mathrm{Pb}_{3}^{2+}\left(\mathrm{H}_{2} \mathrm{O}\right)_{2}\left[\left(\mathrm{UO}_{2}\right)_{4} \mathrm{O}_{4}(\mathrm{OH})_{3}\right]_{2}$, becquerelite, $\mathrm{Ca}\left(\mathrm{H}_{2} \mathrm{O}\right)_{8}\left[\left(\mathrm{UO}_{2}\right)_{6} \mathrm{O}_{4}(\mathrm{OH})_{6}\right]$, billietite, $\mathrm{Ba}\left(\mathrm{H}_{2} \mathrm{O}\right)_{7}\left[\left(\mathrm{UO}_{2}\right)_{6} \mathrm{O}_{4}\right.$ $\left.(\mathrm{OH})_{6}\right]$, fourmarierite $\mathrm{Pb}^{2+}{ }_{1-x}\left(\mathrm{H}_{2} \mathrm{O}\right)_{4}\left[\left(\mathrm{UO}_{2}\right)_{4} \mathrm{O}_{3-2 x}(\mathrm{OH})_{4+2 x}\right]$ $(x=0.00-0.50)$, uranophane, $\mathrm{Ca}\left(\mathrm{H}_{2} \mathrm{O}\right)_{5}\left[\left(\mathrm{UO}_{2}\right)\left(\mathrm{SiO}_{3} \mathrm{OH}\right)\right]_{2}$, zippeite, $\mathrm{K}_{3}\left(\mathrm{H}_{2} \mathrm{O}\right)_{3}\left[\left(\mathrm{UO}_{2}\right)_{4}\left(\mathrm{SO}_{4}\right)_{2} \mathrm{O}_{3}(\mathrm{OH})\right]$, and Na-substituted metaschoepite, $\mathrm{Na}_{1-x}\left[\left(\mathrm{UO}_{2}\right)_{4} \mathrm{O}_{2-x}(\mathrm{OH})_{5+x}\right]\left(\mathrm{H}_{2} \mathrm{O}\right)_{n}$. Solutions included: deionized water; aqueous $\mathrm{HCl}$ solutions at $\mathrm{pH} 3.5$ and $2 ; 0.5 \mathrm{~mol} \mathrm{~L}^{-1} \mathrm{~Pb}(\mathrm{II})-, \mathrm{Ba}-, \mathrm{Sr}-, \mathrm{Ca}-, \mathrm{Mg}-, \mathrm{HCl}$ solutions at $\mathrm{pH} 2 ; 1.0 \mathrm{~mol} \mathrm{~L}^{-1} \mathrm{Na}-$ and $\mathrm{K}-\mathrm{HCl}$ solutions at $\mathrm{pH}$; and a $0.1 \mathrm{~mol} \mathrm{~L}^{-1} \mathrm{Na}_{2} \mathrm{CO}_{3}$ solution at $\mathrm{pH} 10.5$. Uranyl mineral basal surface microtopography, micromorphology, and composition were examined prior to, and after dissolution experiments on micrometer scale specimens using atomic force microscopy, scanning electron microscopy, and X-ray photoelectron spectroscopy. Evolution of etch pit depth at different $\mathrm{pH}$ values and experimental durations can be explained using a stepwave dissolution model. Effects of the cation in solution on etch pit symmetry and morphology can be explained using an adsorption model involving specific surface sites. Surface precipitation of the following phases was observed: (a) a highly-hydrated uranyl-hydroxy-hydrate in ultrapure water (on all minerals), (b) a Na-uranyl-hydroxy-hydrate in $\mathrm{Na}_{2} \mathrm{CO}_{3}$ solution of $\mathrm{pH} 10.5$ (on uranyl-hydroxy-hydrate minerals), (c) a Na-uranyl-carbonate on zippeite, (d) $\mathrm{Ba}^{-}$and $\mathrm{Pb}$-uranylhydroxy-hydrates in $\mathrm{Ba}-\mathrm{HCl}$ and $\mathrm{Pb}-\mathrm{HCl}$ solutions of $\mathrm{pH} 2$ (on uranophane), (e) a $\left(\mathrm{SiO}_{x}(\mathrm{OH})_{4-2 x}\right)$ phase in solutions of $\mathrm{pH} 2$ (uranophane), and (f) sulfate-bearing phases in solutions of $\mathrm{pH} 2$ and 3.5 (on zippeite).

\section{Introduction}

Uranyl minerals are common in oxidized portions of $U$ deposits, and their compositions, structures and stabilities are important for understanding the genesis of such deposits [1]. Of the approximately 200 uranyl minerals, the uranyl oxide

\footnotetext{
*Author for correspondence (E-mail: mschindler@laurentian.ca).
}

hydrates, uranyl phosphates, uranyl silicates, and uranyl sulfates are amongst the most common and important. These minerals are important in controlling the mobility of uranium in the contaminated subsurface. For example, the uranyl silicate, boltwoodite, and the uranyl phosphate, metatorbernite, have formed in contaminated sediments of the Hanford site [2-4], uranyl phosphates occur in contaminated soils of the Fernald site [5], and uranyl sulfates are common in altered mine tailings [6]. The interactions of these minerals with aqueous systems, and the details of how they dissolve and precipitate, are integral to understanding and predicting the mobility of uranium.

Uranyl mineral dissolution appears to be complex, affected by factors such as solution $\mathrm{pH}$ and the presence of various cations in solution, and sometimes involving formation of secondary surface precipitates. Such secondary precipitates potentially could armor the underlying uranyl mineral surfaces from further dissolution. A detailed and mechanistic understanding of uranyl mineral dissolution, including the effects of solution $\mathrm{pH}$, cation content, and secondary precipitate formation, is therefore essential for predictive modeling of radionuclide fate and transport in the subsurface.

Schindler et al. [7] developed an approach to calculate the stability of edges on basal surfaces of uranyl-sheet minerals, estimating the relative stability of an edge based on: (1) the bond-valence deficiency of polyhedron chains parallel to those edges, (2) the arrangement of the interstitial complexes, and (3) the shift between the layers. The approach was used to predict the morphology of basal surfaces of uranyl-sheet minerals [8] and to explain growth and dissolution features of uranyl minerals [9-15]. Schindler et al. [11-15] reported on the dissolution features formed at non steady-state conditions on the surface of the uranyl minerals curite, becquerelite, billietite, fourmarierite and uranophane (Table 1).

This paper expands upon the previous experiments by incorporating mineral surface compositional analysis by X-ray photoelectron spectroscopy (XPS), in addition to morphological analysis by scanning electron microscopy (SEM) and atomic force microscopy (AFM); comparing dissolution features and dissolution-precipitation processes on the surfaces of a broader suite of uranyl minerals; and determining 
Table 1. Examined uranyl minerals, their chemical composition and references for the analytical work.

\begin{tabular}{|c|c|}
\hline Mineral & Reference for analytical work \\
\hline Curite, $\mathrm{Pb}_{3}^{2+}\left(\mathrm{H}_{2} \mathrm{O}\right)_{2}\left[\left(\mathrm{UO}_{2}\right)_{4} \mathrm{O}_{4}(\mathrm{OH})_{3}\right]_{2}$ & AFM studies in [11] \\
\hline Becquerelite, $\mathrm{Ca}\left(\mathrm{H}_{2} \mathrm{O}\right)_{8}\left[\left(\mathrm{UO}_{2}\right)_{6} \mathrm{O}_{4}(\mathrm{OH})_{6}\right]$ & $\begin{array}{l}\text { AFM and SEM studies in [12]; In-situ dissolution } \\
\text { experiments and XPS studies in this work }\end{array}$ \\
\hline Billietite, $\mathrm{Ba}\left(\mathrm{H}_{2} \mathrm{O}\right)_{7}\left[\left(\mathrm{UO}_{2}\right)_{6} \mathrm{O}_{4}(\mathrm{OH})_{6}\right]$ & $\begin{array}{l}\text { AFM, SEM, FT-IR and LA-ICP-MS studies in [13], } \\
\text { XPS studies in this work }\end{array}$ \\
\hline $\begin{array}{l}\text { Fourmarierite, } \\
\mathrm{Pb}^{2+}{ }_{1-x}\left(\mathrm{H}_{2} \mathrm{O}\right)_{4}\left[\left(\mathrm{UO}_{2}\right)_{4} \mathrm{O}_{3-2 x}(\mathrm{OH})_{4+2 x}\right] \\
(x=0.00-0.50)\end{array}$ & AFM and SEM studies in [14] \\
\hline $\begin{array}{l}\text { Uranophane, } \\
\mathrm{Ca}\left(\mathrm{H}_{2} \mathrm{O}\right)_{5}\left[\left(\mathrm{UO}_{2}\right)\left(\mathrm{SiO}_{3} \mathrm{OH}\right)\right]_{2}\end{array}$ & AFM, XPS and SEM studies in [15] \\
\hline Zippeite, $\mathrm{K}_{3}\left(\mathrm{H}_{2} \mathrm{O}\right)_{3}\left[\left(\mathrm{UO}_{2}\right)_{4}\left(\mathrm{SO}_{4}\right)_{2} \mathrm{O}_{3}(\mathrm{OH})\right]$ & AFM and XPS experiments in this study \\
\hline $\begin{array}{l}\text { Na-substituted metaschoepite, } \\
\mathrm{Na}_{1-x}\left[\left(\mathrm{UO}_{2}\right)_{4} \mathrm{O}_{2-x}(\mathrm{OH})_{5+x}\right]\left(\mathrm{H}_{2} \mathrm{O}\right)_{n}\end{array}$ & AFM and XPS experiments in this study \\
\hline
\end{tabular}

the effects of $\mathrm{pH}$, time, and the presence of different electrolyte (cation-containing) solutions. Comparisons include data from earlier studies (see above) in addition to new dissolution studies on becquerelite, billietite, zippeite, and $\mathrm{Na}-$ substituted metaschoepite (Table 1).

\subsection{Selection of uranyl minerals}

The selection of a uranyl mineral for single-crystal dissolution experiments were based on its availability, crystal structure, dimension of its basal face, solubility (or estimated solubility if no solubility constant was available) and environmental importance. For example, metaschoepite, becquerelite and uranophane are common uranyl minerals in the vadose zone of uranium ore deposits [16] and minerals of the zippeite-group are common in sulfate-rich mine tailings of uranium mines. Crystals of these minerals with relatively large basal surfaces $(>50 \times 50 \mu \mathrm{m})$ became available through synthesis experiments by Burns and coworkers [17-20]. Furthermore, their relative high solubility in comparison to e.g. minerals of the autunite group [22] allowed in situ AFM dissolution experiments.

Conversely, the uranyl minerals billietite, fourmarierite, and curite are less common than metaschoepite, becquerelite and uranophane. Fourmarierite and billietite were selected because their structures contain sheets of polymerized uranyl-polyhedra which are topologically identical to the sheets in the structures of metaschoepite and becquerelite, respectively. These structural similarities allowed comparisons between dissolution features on minerals with presumably similar surface-structures but different bulk composition.

Curite was selected as the first mineral for dissolution experiments because crystals with basal surfaces in the millimeter range could be easily synthesized under hydrothermal conditions and the morphology of naturally occurring etch pits seemed to contradict the space-group symmetry of its crystal structure [11].

\section{Experimental}

Most minerals were obtained from the William W. Pinch collection at the Canadian Museum of Nature, and from the collection of the late Gilbert Gauthier. All mineral samples are originally from the Shinkolobwe Mine, Democratic Republic of Congo. Additionally, zippeite, uranophane, becquerelite and Na-substituted metaschoepite were synthesized according to the methods of Burns et al. [17], Klingensmith and Burns [18], Burns and Li [19] and Klingensmith et al. [20], respectively. Phase identity and purity were verified using diffraction patterns collected with a Scintag theta-theta diffractometer with $\mathrm{Cu} K_{\alpha}$ radiation. Chemical compositions of some of the minerals were analysed with a Cameca SX-100 elelctron microprobe operating in wavelength-dispersion mode with an accelerating voltage of $15 \mathrm{kV}$, a specimen current of $10 \mathrm{nA}$ and a beam diameter of $5 \mu \mathrm{m}$. Raw intensities were converted to concentrations using the PAP matrix correction software [21].

\subsection{Single-crystal dissolution experiments}

Atomic force microscopy of dissolution features on single crystals can be carried out in situ (i.e. in a fluid cell) or after batch dissolution experiment. The duration of an in situ dissolution experiment is commonly limited to several hours and requires therefore relative fast dissolution rates of the dissolving mineral. A batch dissolution experiment for subsequent AFM examination must be conducted over a short period of time $(<1 \mathrm{~h})$, because secondary phases may precipitate during longer experiments on the surface of the dissolving mineral, complicating or even preventing the imaging of dissolution features.

For the latter two reasons, in situ and short batchdissolution experiments $(<1 \mathrm{~h})$ were carried out at low $\mathrm{pH}$-value $(\mathrm{pH}=2)$, where the dissolution rate of uranyl minerals is commonly faster than under weak acidic, neutral or basic conditions. Similarly, dissolution experiments on curite were conducted at elevated temperatures $\left(60^{\circ} \mathrm{C}\right)$, at which secondary precipitates did not form on the surface of the mineral.

One goal of our study was also the characterization of secondary precipitates on the surface of uranyl minerals. Precipitation of any secondary U-bearing phase is more likely under weak acidic, neutral and basic conditions, where the stability of uranyl minerals is commonly higher than under strong acidic conditions [22]. Conse- 
quently, longer dissolution experiments $(>1 \mathrm{~h})$ were conducted at room temperature in distilled water and under weak acidic $(\mathrm{pH}=3.5)$, and basic conditions $(\mathrm{pH}=10.5)$.

The dissolution experiments in this study were intended to examine dissolution or dissolution-precipitation features on the surface of uranyl minerals. Organic or inorganic ions in solution can modify dissolution- or growth features on a mineral surface [23 or see below]. Hence, none of the dissolution experiments in this study were carried out with an additional organic or inorganic buffer that could have potentially modified dissolution or growth features on the surface of a uranyl mineral.

\subsubsection{Dissolution experiments}

Prior to batch dissolution experiments, crystals (typically 50-300 $\mu \mathrm{m}$ ) were mounted on double-sided $\mathrm{C}$ tape and placed in polyethylene cups containing solutions. Table 2 lists the electrolyte solutions used, initial $\mathrm{pH}$, and ionic strength. An Accumet 950 (Fisher Scientific) pH meter was used with a glass combination electrode for $\mathrm{pH}$ measurement. The $\mathrm{pH}$-meter was calibrated with a $\mathrm{KCl}-\mathrm{HCl}$ buffer solution of $\mathrm{pH} 2$ and an ionic strength of $I=0.2$. The buffer was created by mixing $50 \mathrm{~mL}$ of a $0.2 \mathrm{M} \mathrm{KCl}$ aqueous solution and $13 \mathrm{~mL}$ of a $0.2 \mathrm{M} \mathrm{HCl}$ aqueous solution [24]. The ionic strength of this buffer solution was lower than the ionic strength of some of the electrolyte solutions (Table 2). However, the uncertainty arising from this calibration is most likely smaller than the uncertainty of the actual $\mathrm{pH}$ measurement $( \pm 0.2)$, which was estimated on the basis of multiple $\mathrm{pH}$ measurements on solutions of high ionic strength.

Dissolution experiments on curite were performed at $60{ }^{\circ} \mathrm{C}$ for $24 \mathrm{~h}$ in solutions of $\mathrm{pH} 2,3.5$, and in ultrapure water. Dissolution experiments on all other uranyl minerals were at room temperature $\left(\sim 22{ }^{\circ} \mathrm{C}\right)$. Experiments in ultrapure water and in a $\mathrm{Na}_{2} \mathrm{CO}_{3}$ aqueous solution of $\mathrm{pH} 10.5$ lasted for $24 \mathrm{~h}$, in aqueous $\mathrm{HCl}$ solution of $\mathrm{pH} 3.5$ for $3 \mathrm{~h}$, and in solutions of $\mathrm{pH} 2$ between 10 and $30 \mathrm{~min}$. Dissolution features on the surface of becquerelite were monitored using in-situ AFM in a $\mathrm{HCl}$ solution of $\mathrm{pH}$ 2. The liquid in the fluid cell was replaced with fresh solution every $20 \mathrm{~min}$ using a manual injection system.

Table 2. Solutions used in the dissolution experiments, their concentration (molarity and molality), initial $\mathrm{pH}$ and ionic strength.

\begin{tabular}{lccc}
\hline $\begin{array}{l}\text { Electrolyte } \\
\text { solution }\end{array}$ & $\begin{array}{c}\text { Molality } \\
\text { mol kg}\end{array}$ & $\begin{array}{c}\text { pH-value } \\
\text { initial }\end{array}$ & $\begin{array}{c}\text { Ionic strength } \\
\text { (molality) }\end{array}$ \\
\hline $1.0 \mathrm{~mol} \mathrm{~L}^{-1} \mathrm{NaCl}$ & 1.06 & 2.0 & 1.07 \\
$1.0 \mathrm{~mol} \mathrm{~L}^{-1} \mathrm{KCl}$ & 1.08 & 2.0 & 1.09 \\
$0.5 \mathrm{~mol} \mathrm{~L}^{-1} \mathrm{BaCl}_{2}$ & 0.55 & 2.0 & 1.51 \\
$0.5 \mathrm{~mol} \mathrm{~L}^{-1} \mathrm{SrCl}_{2}$ & 0.54 & 2.0 & 1.45 \\
$0.5 \mathrm{~mol} \mathrm{~L}^{-1} \mathrm{MgCl}_{2}$ & 0.52 & 2.0 & 1.12 \\
$0.5 \mathrm{~mol} \mathrm{~L}^{-1} \mathrm{CaCl}_{2}$ & 0.53 & 2.0 & 1.26 \\
$\left.0.5 \mathrm{~mol} \mathrm{~L}^{-1} \mathrm{~Pb}_{\mathrm{NO}}\right)_{2}$ & 0.58 & 2.0 & 0.91 \\
$0.1 \mathrm{~mol} \mathrm{~L}^{-1} \mathrm{Na}_{2} \mathrm{CO}_{3}$ & 0.11 & 10.5 & 0.22 \\
$\mathrm{HCl}$ & 0.01 & 2.0 & 0.01 \\
$\mathrm{HCl}$ & $10^{-3.5}$ & 3.5 & 0.0003 \\
\hline
\end{tabular}

a: Note that the electrolyte solutions of $\mathrm{pH} 2.0$ have equal normality.
After solution exposure, the crystals were quickly dried by touching a kimwipe to the edge to wick away moisture, washed in de-ionized water and prepared for AFM, scanning electron microscopy, optical-reflection microscopy and XPS. The time between the dissolution experiment and AFM examination was a critical issue, because the surface properties of some of the samples altered with time (see below). Most of the AFM examinations were done $12 \mathrm{~h}$ after the dissolution experiments, but in some cases, the surfaces were examined three days after the dissolution experiment.

The saturation indices with respect to schoepite and amorphous silica, and the ionic strength of the electrolyte solutions, were calculated using Visual MINTEQ 2.53 [25]. The ionic strength $(I)$ of the electrolyte solutions with $I>0.90$ were calculated using the Brønsted-GuggenheimScatchard version of the specific ion interaction theory (SIT) [26] and the aqueous-species interaction coefficients from the MINTEQ database.

\subsection{Atomic-force microscopy (AFM) and scanning electron microscopy (SEM)}

Basal surfaces of reacted and unreacted uranyl-minerals were scanned in contact mode with a Nanoscope III AtomicForce Microscope (Veeco Digital Instruments). In order to verify that scanning did not induce erosion of the surface and subsequent alteration of the pit shape, or that drift did not substantially distort shape, scanning was always repeated at least twice in orthogonal directions (except for the in-situ imaging). SEM was performed with a 120 Stereoscan instrument from Cambridge Instruments with chemical analysis by an EDAX Genesis system 4000 .

\subsection{Surface composition analysis by X-ray photoelectron spectroscopy (XPS)}

Basal surface chemical composition was analyzed with a Kratos Axis Ultra X-ray XPS equipped with a magneticconfinement charge-compensation system. For XPS measurements of untreated samples, single crystals were cleaved in air and immediately transferred to the XPS. Spectra were collected in high-resolution scans using monochromatic $\mathrm{Al} K_{\alpha}$ radiation $(1486.6 \mathrm{eV})$ and the charge-compensation system. Spectra were recorded using 20 sweeps, scan rates per sweep of $200 \mathrm{~ms}$ with analyzer pass-energies of 80 and $160 \mathrm{eV}$ and with an aperture size of $55 \mu \mathrm{m}$. Resolution for the different pass-energies and aperture and their effect on the FWHM values (FWHM = full width at half maximum) of the $\mathrm{U} 4 f$ and $\mathrm{O} 1 s$ peaks are described in detail in Schindler et al. [27, 28]. Shirley background corrections [29], Gaussian-Lorentzian peak shapes and asymmetric peak shapes were used to fit the $\mathrm{U} 4 f$ and $\mathrm{O} 1 s$ spectra, respectively. Electrostatic sample-charging, which was not compensated by the charge neutraliser, was corrected by setting the binding energy of the $\mathrm{C} 1 s$ electrons of adventitious $\mathrm{C}$ on the sample surface equal to $285 \mathrm{eV}$ [30]. We use the word band to indicate a specific fitted component of the envelope of the $\mathrm{O} 1 s$ and $\mathrm{U} 4 f$ peaks, and we use the word species to indicate $\mathrm{U}$ atoms of different valence, structurally distinct $\mathrm{O}^{2-}$, or $\mathrm{U}$-atoms in a small cluster of atoms involving $\mathrm{O}^{2-}$. 


\section{General composition of the surface}

After Shirley background corrections, the areas of the $\mathrm{U} 4 f_{7 / 2}, \mathrm{Si} 2 p, \mathrm{Ca} 2 p, \mathrm{~S} 2 p, \mathrm{~K} 2 p, \mathrm{Ba} 3 d, \mathrm{Na} 1 s$ and $\mathrm{O} 1 s$ peaks were used to calculate the mole proportions of $\mathrm{U}, \mathrm{Si}$, $\mathrm{Ca}, \mathrm{S}, \mathrm{K}, \mathrm{Ba}, \mathrm{Na}$ and $\mathrm{O}$ on the surfaces of the corresponding minerals. We tried different sets of Relative Sensitivity Factors (RSF) for the calculation of the mole proportion of the elements. The best results were obtained using the sensitivity factors from the Vision 2.2.6 software [31] for $\mathrm{S}, \mathrm{Ca}, \mathrm{K}, \mathrm{Ba}$ and $\mathrm{O}$ and 8.476 for $\mathrm{U} 4 f_{7 / 2}$ [30]. These sensitivity factors gave a reasonably good agreement between the ratios of the elements on the surface of untreated crystals and their bulk composition. Use of the sensitivity factor for $\mathrm{Si}$ of 0.325 (Vision 2.2.6, [31]) resulted in lower $\mathrm{U}$ : $\mathrm{Si}$ and larger $\mathrm{Si}: \mathrm{Ca}$ ratios with respect to the bulk composition of uranophane. Hence, the sensitivity factor for the $\mathrm{Si} 2 p$ spectrum was derived by measuring the $\mathrm{U}: \mathrm{Si}$ ratio of four different untreated surfaces of uranophane and uranophane- $\beta$ (see [15] for details). The resulting sensitivity factor of 0.57 was used to calculate mole proportions of all samples. This factor allowed us to examine in more detail the change in $\mathrm{O}: \mathrm{Si}$ and $\mathrm{O}: \mathrm{U}$ ratios between different uranophane samples.

The chemical composition of a surface determined with $\mathrm{X}$-ray photoelectron spectroscopy is commonly reported in ratios between the atomic proportions of two elements or in changes of these ratios with respect to a standard surface (e.g. an untreated surface). The standard deviation of a ratio between the atomic proportions of two elements is circa \pm 0.1 and is based on the uncertainty of the size of a quantification area of an element.

\section{The $\mathrm{U} 4 f_{7 / 2}$ spectrum}

The presence and proportion of $\mathrm{U}^{6+}$ and $\mathrm{U}^{4+}$ were determined by peak fitting the $U 4 f_{7 / 2}$ spectra and examining satellite peaks of the $\mathrm{U} 4 f_{5 / 2}$ peak. Previously reported binding energies for $\mathrm{U}^{6+}, \mathrm{U}^{5+}$ and $\mathrm{U}^{4+}$ in the $\mathrm{U} 4 f_{7 / 2}$ peaks of uranyl minerals and mixed-valent U-compounds were used to identify the different U-bands. Separations between the bands are similar for many compounds and have average values of 0.9 for $\mathrm{U}^{6+}-\mathrm{U}^{5+}$ and $0.6 \mathrm{eV}$ for $\mathrm{U}^{5+}-\mathrm{U}^{4+}$ [27]. Schindler et al. [27] showed that the chemical shifts of the $\mathrm{U}^{6+}$ and $\mathrm{U}^{4+}$ bands in the $\mathrm{U} 4 f_{7 / 2}$ peak for uranyl minerals are between $381.0-382.3$ and $380.2-380.7 \mathrm{eV}$, respectively. Here, the average binding energies of the $\mathrm{U}^{6+}$ and $\mathrm{U}^{4+}$ bands shift to lower values with (1) incorporation of divalent cations, and (2) increase in the Lewis basicity of the anion group bonded to $\mathrm{U}$.

Important for this study is the observed chemical shift of the $\mathrm{U}^{6+}$ band in $\mathrm{U} 4 f_{7 / 2}$ spectra for uranyl-hydroxyhydrate minerals. Here, Schindler et al. [27] showed that the $\mathrm{U}^{6+}$ band for uranyl-hydroxy-hydrate compounds with no or small portions of monovalent interstitial cations occurs at $382.0-382.3 \mathrm{eV}$ while the same band occurs at $381.0-381.6 \mathrm{eV}$ in the spectra of uranyl-hydroxy-hydrate minerals with divalent interstitial cations.

The FWHM values of the bands for $\mathrm{U}^{6+}$ and $\mathrm{U}^{4+}$ vary from $1.00-1.40 \mathrm{eV}$ in the $\mathrm{U} 4 f_{7 / 2}$ spectra measured for this study. They were constrained to be equal in each individual spectrum. Additional details on fitting procedure and characteristic binding energies for $\mathrm{U}^{6+}$ bands in other uranyl minerals can be found in Schindler et al. [27].

\section{The $\mathrm{O} 1$ s spectrum}

The $\mathrm{O} 1 s$ spectra were fitted in order to resolve the signals from the different $\mathrm{O}$ bands. Schindler et al. [28] showed that one can distinguish the following O-bands in the $\mathrm{O} 1 \mathrm{~s}$ spectra of uranyl-oxysalt minerals:

(1) 529.0-530.0 eV: $\mathrm{O}^{2-}$ in the equatorial plane of the uranyl polyhedra and bonded exclusively to $\mathrm{U}$ (indicated as $\mathrm{U}-\mathrm{O}-\mathrm{U})$

(2) 530.5-531.4 eV: $\mathrm{O}^{2-}$ of the uranyl group (which are involved in bonds of higher $\pi$-bonding character), indicated as $\mathrm{O}=\mathrm{U}=\mathrm{O}$

(3) $531.2-531.4 \mathrm{eV}: \mathrm{O}^{2-}$ in the equatorial plane (which are part of the silicate tetrahedra, indicated as $\mathrm{T}-\mathrm{O}$ );

(4) 531.8-533.0 eV: OH groups in the equatorial plane (indicated as $\mathrm{OH})$;

(5) 533.0-534.0 eV: $\mathrm{H}_{2} \mathrm{O}$ groups in the interstitial complex (indicated as $\mathrm{H}_{2} \mathrm{O}_{\text {interst }}$ );

(6) $>534.0 \mathrm{eV}: \mathrm{H}_{2} \mathrm{O}$ groups physisorbed on the basal surface (indicated as $\mathrm{H}_{2} \mathrm{O}_{\text {adsorb }}$ ).

Chemical compositions of surfaces with respect to the proportion of $\mathrm{O}$ components will be given in atomic ratios between two different O-components. The uncertainty of such a ratio is approximately \pm 0.2 and is based on the variation of an individual band area by $\pm 2 \%$ (for details see Schindler et al. $[15,28])$.

More details on fitting procedures, constraints on the binding energies of the different O-bands, contributions of $\mathrm{C}-\mathrm{O}$ bearing species and an error estimation on the relative proportions of the bands in the $\mathrm{O} 1 s$ spectrum are given by Schindler et al. $[15,28]$.

\section{Results and discussion}

This section is organized into three main themes: (1) change in morphology of etch pits with $\mathrm{pH}$, solution saturation, and/or duration of an experiment (interpretation based on the stepwave dissolution model); (2) change in morphology of etch pits with the type of cation in solution: interpretation based on mechanisms of cation adsorption and mineral structure; and (3) observations of secondary phase precipitation over the course of dissolution: implications for dissolution phenomena and radionuclide remobilization. Each of these sections begins with several key observations from experiments on selected uranyl minerals, followed by a discussion of the theoretical underpinnings for interpreting the experimental observations, and is concluded with a brief summary including discussion or implications.

\subsection{Change in morphology of etch pits with $\mathrm{pH}$, solution saturation, and/or duration of an experiment}

In this section, we will first discuss the change in etch pit morphology with a change in $\mathrm{pH}$ over the same reaction time and then describe the change in etch pit morphology with duration of a batch and in situ dissolution experiment at constant $\mathrm{pH}$. 


\subsubsection{Change in etch pit morphology with the change in $\mathbf{p H}$}

A change in etch pit morphology with a change in $\mathrm{pH}$ over the same reaction time were examined in the dissolution experiments on curite, $\mathrm{Pb}_{3}^{2+}\left(\mathrm{H}_{2} \mathrm{O}\right)_{2}\left[\left(\mathrm{UO}_{2}\right)_{4} \mathrm{O}_{4}(\mathrm{OH})_{3}\right]_{2}$ (Schindler et al. [11]). As indicated above, all dissolution experiments were conducted at $60{ }^{\circ} \mathrm{C}$ in order to prevent the formation of secondary precipitates on the surface of curite at $\mathrm{pH} 3.5$ and in distilled water.

Fig. 1a shows typical etch pits on the (100) surface of curite formed in distilled water and Fig. 1b shows cross sections of etch pits formed at $\mathrm{pH} 2.1$ and 3.5 and in distilled water. The cross sections were taken parallel to the [010] edge (which is approximately parallel to the elongation of the etch pits) and are characterized by steep edges and convex surfaces. Etch pits formed at pH 2.1 have lower relief and larger lateral extent than etch pits formed at $\mathrm{pH} 3.5$. Here, higher relief of an etch pit is not the result of a faster dissolution rate perpendicular to the sheets; rather, it is an expression of the difference between the lowering of the surrounding surface through dissolution, and growth of the etch pit perpendicular to the sheet [11].

\subsubsection{Change in etch pit morphology with the duration of a batch experiment}

A change in etch pit morphology with the duration of a batch dissolution experiment (10 and $30 \mathrm{~min})$ at $\mathrm{pH}=2$ was examined in dissolution experiments on uranophane, $\mathrm{Ca}\left(\mathrm{H}_{2} \mathrm{O}\right)_{5}\left[\left(\mathrm{UO}_{2}\right)\left(\mathrm{SiO}_{3} \mathrm{OH}\right)\right]_{2}$ [15]. Fig. 1c shows typical etch pits on the basal (100) surface of uranophane after treatment with an $\mathrm{HCl}$ solution of $\mathrm{pH} 2$ for $30 \mathrm{~min}$.
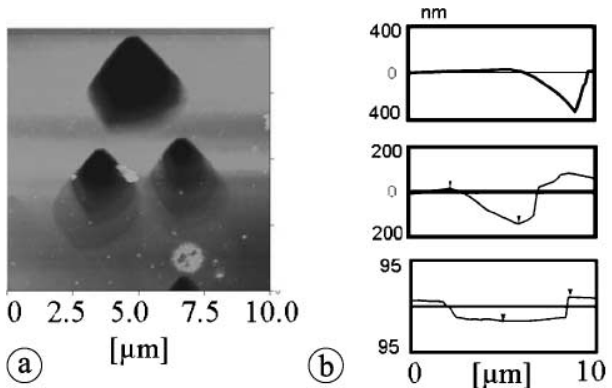

$\mathrm{pH}$-value

Ultrapure water

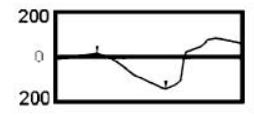

3.5

(b)

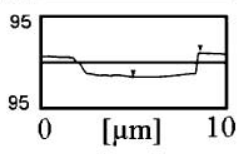

2.0

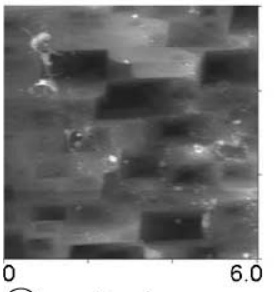

(c) $[\mu \mathrm{m}]$

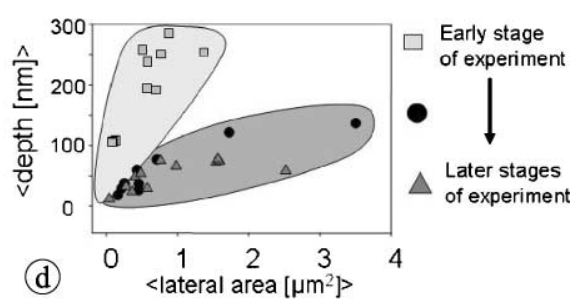

Fig. 1. (a) AFM images in height mode of etch pits formed on the curite (100) surface in ultrapure water; (b) cross sections of etch pits formed in ultrapure water, in an $\mathrm{HCl}$ solution of $\mathrm{pH} 3.5$, and in an $\mathrm{HCl}$ solution of $\mathrm{pH} 2.1$ on the curite (100) surface; (c) AFM image in height mode of parts of the basal surface of uranophane treated with an $\mathrm{HCl}$ solution of $\mathrm{pH} 2$ for $30 \mathrm{~min}$; (d) the average lateral area as a function of the average depth of etch pits formed in $\mathrm{HCl}$ solutions of $\mathrm{pH} 2$ on the basal surface of uranophane. (a-b and $\mathbf{c}-\mathbf{d}$ are modified from [11] and [15] respectively).
Fig. 1d shows the area of an etch pit as a function of the average depth observed in the batch experiments. Etch pits formed at an earlier stage of the dissolution experiment at $\mathrm{pH} 2$ have a larger ratio between depth and lateral area than etch pits observed at later stages of the experiment. Schindler et al. [15] showed that the degree of undersaturation with respect to uranophane decreases with duration of the experiment. Hence, the ratio between the lowering of the surface and the growth of the etch pit perpendicular to the sheet decreases with decreasing undersaturation of the solution with respect to uranophane.

\subsubsection{Change in etch pit morphology with the duration of an in situ experiment}

The change in morphology with the duration of an in situ experiment at $\mathrm{pH}=2$ was conducted on a single crystal of becquerelite, $\mathrm{Ca}\left(\mathrm{H}_{2} \mathrm{O}\right)_{8}\left[\left(\mathrm{UO}_{2}\right)_{6} \mathrm{O}_{4}(\mathrm{OH})_{6}\right]$. Fig. $2 \mathrm{a}-\mathrm{d}$ shows the growth of etch pits on the basal surface of becquerelite in situ after injection of an $\mathrm{HCl}$ solution at $\mathrm{pH} 2$. The etch pits are elongated parallel to [100] and changes in their relief and lateral dimensions vary with experiment duration. Relief and lateral dimensions strongly increase during the first minutes of the experiment. In the latter stages of the experiment, lateral dimension parallel to the elongation of the pit shows a noticeable increase, whereas relief and growth of the pit perpendicular to the elongation decreases or increase only slightly, respectively. Fig. 2e,f shows growth rate parallel to the elongation of the pit (in $\mathrm{nm} / \mathrm{s}$ ) vs. growth rate perpendicular to the elongation of the pit and vs. change in relief of the pit, respectively. Both plots indicate exponential relations with maximum growth rates and changes in relief in the first minutes of the experiment. Although we did not monitor changes in solution composition, dissolution of becquerelite in a closed system should result in a decrease in the degree of undersaturation with respect to becquerelite as reaction products accumulate in solution.

\subsubsection{The dissolution stepwave model}

Observations from dissolution experiments on curite, uranophane and becquerelite demonstrate that etch pit relief decreases with decreasing $\mathrm{pH}$ and increasing degree of saturation. These observations can be explained in light of the dissolution stepwave model, which describes the role of etch pits in terms of their ability to generate a continual sequence of steps [32-34]. The peripheries of etch pits contain a number of steps that migrate into the rest of the mineral surface during dissolution. The continuous movement of these steps into the mineral surface produces dissolution stepwaves. As dissolution progresses, these stepwaves control the overall dissolution rate of the crystal.

The spreading rate of a stepwave depends on the dissolution rate perpendicular to each edge, which can be expressed by either (1) the retreat velocity of steps with identical height, or (2) the lowering of the surface relative to an unchanged reference point on that surface. Here, the area of the upper layer of an etch pit (in $\left[\mu^{2}\right]$ ) may indicate the general stability of an edge, and the depth of an etch pit (in [nm]) may express the change in relief of an etch pit with respect to the surrounding surface. This change in relief depends on the 


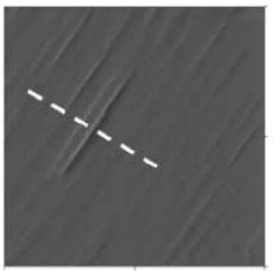
0 (a) 0 min. $5 \mu \mathrm{m} 0$
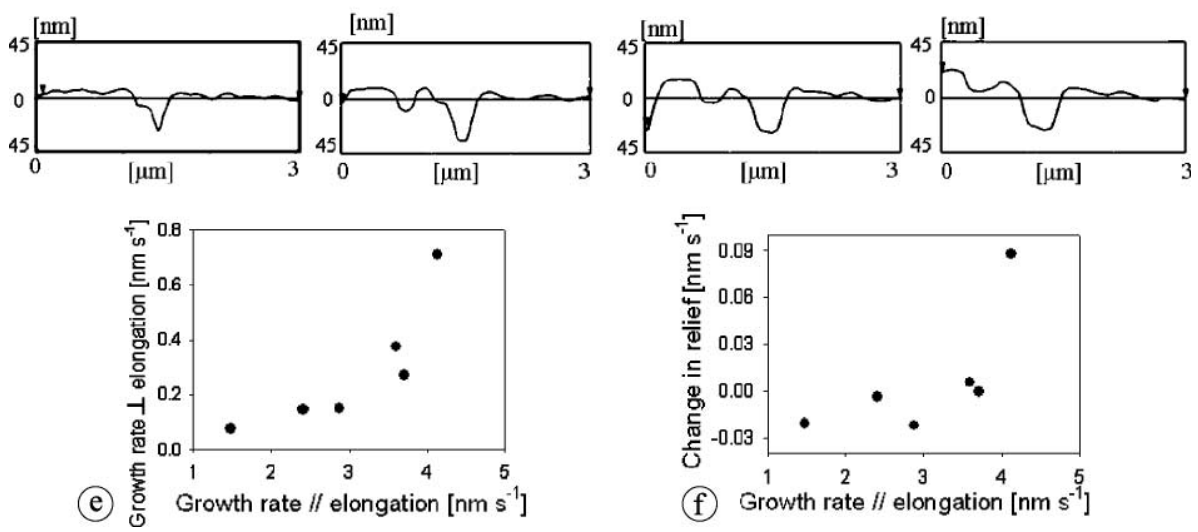

Fig. 2. (a-d) In-situ AFM images in deflection mode and cross sections of an etch pit formed on the basal surface of becquerelite in an $\mathrm{HCl}$ solution of $\mathrm{pH} 2$. The number of minutes beside each AFM image indicates the time elapsed with recording of the first image, which was taken shortly after injection of the solution into the fluid cell. The first image was taken shortly after injection of the solution and is labelled 0 minutes. The time span between the recording of the each consecutive image and the first image is given in minutes; $(\mathbf{e}-\mathbf{f})$ growth rate of the etch pit parallel to the elongation of the pit $\left[\mathrm{nm} \mathrm{s}^{-1}\right]$ as a function of (e) the growth rate of the etch pit perpendicular to the elongation of the pit and, (f) the relief of the etch pit. ratio of the lowering of the surrounding surface to the growth of an etch pit perpendicular to the basal face.

\subsubsection{Change in relief as a function of $\mathrm{pH}$ and saturation state}

The change in relief of etch pits is sensitive to $\mathrm{pH}$. As $\mathrm{pH}$ increases, the degree of protonation of the edge sites decreases, and their general stability is therefore higher than at lower $\mathrm{pH}$. The higher stability of an edge at relatively higher $\mathrm{pH}$ (i.e., in deionized water) prevents the formation of stepwaves and thus the lowering of the surrounding surface. Because of the decrease in number of stepwaves at higher $\mathrm{pH}$, greater relief of an etch pit at higher $\mathrm{pH}$ indicates an increased ratio of etch pit growth perpendicular to the sheet relative to lowering of the surrounding surface (which is lessened by decrease in stepwaves).

The formation of etch pits generally depends on the character of the dislocations (i.e. strain energy and the size of the dislocation cores) and the saturation state of the solution $($ e.g. $[35,36])$. Etch pits may be 3-dimensional, forming at dislocations and penetrating deep into the crystal, or 2-dimensional, forming in defect-free areas or at point defects and remaining shallow. In general, etch pit nucleation increases with degree of undersaturation of the solution. Above a critical saturation state, no new etch pits can nucleate and dissolution at steps becomes the dominant dissolution mechanism (e.g. [37, 38]). At extremely low saturation states (i.e., highly undersaturated), two-dimensional surface nucleation of etch pits in dislocation-free areas becomes operative [39].

The structures of curite, uranophane and becquerelite are characterized by sheets of polymerized uranyl polyhedra. Dislocation effects in structures based on sheets of polymerized polyhedra involve point defects and result in gliding of layers of polyhedra parallel to the basal surface (e.g. [40]). Etch pit nucleation and growth perpendicular to the basal surface of uranyl minerals is thus controlled by the occurrence and number of point defects between the layers of polymerized uranyl-polyhedra.

The results of dissolution experiments on uranophane and becqurelite show that the ratio between the growth rate perpendicular to the surface vs. the lowering of the surrounding surface by stepwaves decreases with increasing saturation state. This phenomenon must involve a change in the growth rate of the pit perpendicular to the basal surface and the formation of stepwaves peripheral to the etch pits. For example, at higher saturation states, the growth of an etch pit perpendicular to the basal face may be limited by the occurrence of point defects in the underlying sheets. At lower saturation states, the etch pits may have grown perpendicular to the basal face through continuous etchpit nucleation on defect-free areas at the bottom of the pits. After this initial formation of an etch pit, stepwaves move into the rest of the crystal and continuously lower the surface. In a system in which saturation state changes over the course of the reaction, the surface surrounding the etch pit flattens out and the etch pit becomes more shallow than those formed at the start of the dissolution experiment.

\subsubsection{Conclusions on the change in morphology of etch pits with $\mathbf{p H}$ and saturation state}

Dissolution experiments at different $\mathrm{pH}$ values and experimental durations showed that the depth of an etch pit on the surface of a uranyl mineral decreases with decreasing $\mathrm{pH}$ and increasing saturation state of the solution. The depth of an etch pit expresses the ratio between the growth of an etch pit perpendicular to the surface and the lowering of the surrounding surface. This ratio is controlled by dissolution stepwaves that migrate from the etch pits into the rest of the mineral surface (flattening of the surface) and the growth rate of an etch pit at different saturation states. 


\subsection{Change in morphology of etch pits with the type of cation in solution}

Morphologies of etch-pits are discussed in detail for minerals with topological identical sheets of polymerized uranyl polyhedral. These minerals are bequerelite/billietite and fourmarierite/Na-bearing metaschoepite. Furthermore, etch pits formed on the surface of zippeite are discussed followed by an overall discussion on the relationship between the morphology of etch pits and structural parameter such as adsorption sites of cationic aqueous species and arrangements of sheets of polymerized uranyl polyhedra.

The effect of the type of cation in solution on the morphology of etch pits can be determined only if one has information on the morphology of the underlying crystal, the stability of basal-surface edges and the arrangement of interstitial cations. Hence, we begin by discussing the structure and crystal morphology of each mineral used in dissolution experiments aimed at determining the effects of cations in solution.

\subsubsection{Becquerelite and billietite}

Becquerelite and billietite contain the structural unit $\left[\left(\mathrm{UO}_{2}\right)_{6} \mathrm{O}_{4}(\mathrm{OH})_{6}\right]^{2-}$ in which $\mathrm{U}^{6+}$ occurs in 7-coordination by two apical uranyl-ion $\mathrm{O}$-atoms, by three equatorial $(\mathrm{OH})$ groups and two equatorial $\mathrm{O}^{2-}$ atoms (Fig. 3a) [19, 41, 42]. The $(\mathrm{OH})$-groups occur at the corners of the triangular holes in the sheet of polyhedra. The apical $\mathrm{U}=\mathrm{O}$ uranyl bonds are not involved in linkage between uranyl polyhedra, and point up and down into the interstices (Fig. 4e,f).

Becquerelite and billietite have orthorhombic symmetry, but space group symmetry and unit-cell dimensions vary with the type of interstitial cation and the number of interstitial $\left(\mathrm{H}_{2} \mathrm{O}\right)$ groups. We will use the dimensions $a=$ $13.8527 / 2=6.926 \AA, b=12.393 \AA$ and $c=14.930 \AA$ from the structural data of becquerelite [19] to describe the crystal

(a)

[100]

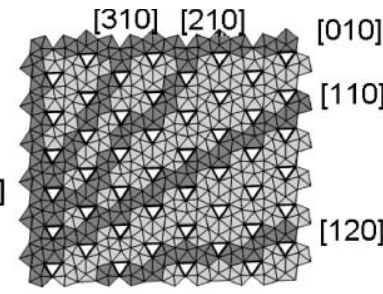

(b)
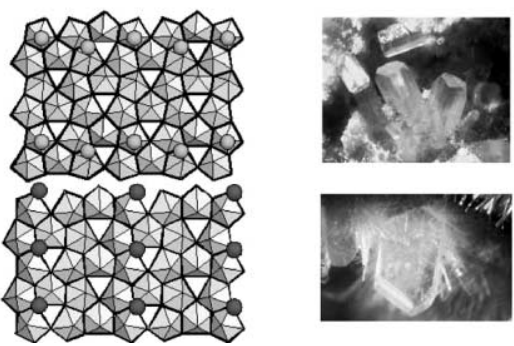

[010] [110]

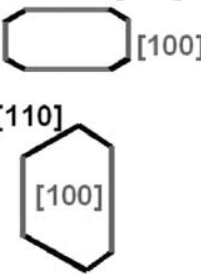

Fig. 3. (a) Polyhedron representation of the uranyl-oxide-hydroxyhydrate sheet in becquerelite; polyhedron chains parallel to [100], [010], [110], [210], [310] and [130] are highlighted in different shades of grey, and the positions of the $(\mathrm{OH})$ groups are shown as vertices of black triangles; (b-c) polyhedron illustrations of layers in (b) becquerelite and (c) billietite, showing the positions of interstitial $\mathrm{Ca}$ (light-grey circles) and $\mathrm{Ba}$ (dark-grey circles); right: examples of the corresponding (001) surface morphologies on becquerelite and billietite (for details, see text and [12] and [13]).

morphology of becquerelite and billietite. Fig. 3b,c shows the arrangements of the interstitial cations, $\mathrm{Ca}$ and $\mathrm{Ba}$, in becquerelite and billietite, respectively. The interstitial $\mathrm{Ca}$ atoms in becquerelite occur in rows parallel to [010] and the interstitial $\mathrm{Ba}$ atoms in billietite occur in rows parallel to [100]. Becquerelite crystals are most commonly elongated parallel to [010] (i.e., parallel to the row of the interstitial Ca atoms), whereas billietite crystals can be elongated parallel to [100] (i.e., parallel to the row of the interstitial Ba atoms, Fig. 3b,c [19]).

\subsubsection{Dissolution experiments in $\mathrm{Ca}-\mathrm{HCl}, \mathrm{Ba}-\mathrm{HCl}$ and Mg-HCl electrolyte solutions}

Fig. 4 summarizes the results of dissolution experiments on the basal surface of becquerelite and billietite in $\mathrm{Ca}-\mathrm{HCl}-$, $\mathrm{Ba}-\mathrm{HCl}-$ and $\mathrm{Mg}-\mathrm{HCl}$-solutions of $\mathrm{pH} 2$ [12, 13]. Etch pits formed on the surface of becquerelite in a Ba-HCl-solution of $\mathrm{pH} 2$ elongate in the same direction as crystals of billietite (Fig. 4a), etch-pits formed on the surface of billietite in a Ca-HCl-solution of $\mathrm{pH} 2$ elongate in the same direction as crystals of bequerelite (Fig. 4b), and etch pits formed on the surfaces of becquerelite and billiteite in $\mathrm{Mg}-\mathrm{HCl}$-solutions of $\mathrm{pH} 2$ have identical orientations (Fig. 4c,d). Furthermore, identical orientations of etch pits occur on the surfaces of becquerelite and billietite treated with $\mathrm{Pb}\left(\mathrm{NO}_{3}\right)_{2}-\mathrm{HCl}$, Ba$\mathrm{HCl}, \mathrm{Sr}-\mathrm{HCl}$, and $\mathrm{Na}-\mathrm{HCl}$ solutions of $\mathrm{pH}$ 2. The only exceptions from this general trend are the orientations of etch pits formed in $\mathrm{K}-\mathrm{HCl}$ solutions of $\mathrm{pH} 2$, where etch pits formed on the surface of becquerelite and billietite elongate parallel to [100] and [310], respectively.

Schindler et al. $[12,13]$ showed that the different orientations of etch pits on the surfaces of becquerelite and billietite

(a)

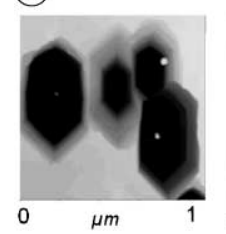

(b)
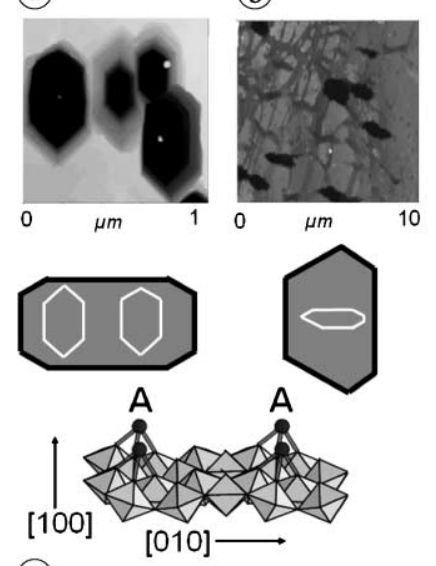

(e)

Fig. 4. (a-d) AFM images in height mode of etch pits formed in (a) $\mathrm{Ba}-\mathrm{HCl}$ solution of $\mathrm{pH} 2$ on the surface of becquerelite; (b) $\mathrm{Ca}-\mathrm{HCl}$ solution of $\mathrm{pH} 2$ on the surface of billietite; (c-d) $\mathrm{Mg}-\mathrm{HCl}$ solution of $\mathrm{pH} 2$ on the surface of (c) becquerelite and (d) billietite; (e) hypothetical $\mathrm{Ba}^{2+}$ at position $\mathrm{A}$ on the surface of the uranyl sheet in the bulk structure of billietite; $\mathrm{Ba}^{2+}$ atoms are shown as black circles and the bonds between $\mathrm{Ba}^{2+}$ and $\mathrm{O}$ atoms of the uranyl groups are shown as dark-grey lines; (f) hypothetical $\mathrm{Ca}^{2+}$ atoms at positions A and B on the surface of the uranyl sheet in the bulk structure of becquerelite; $\mathrm{Ca}^{2+}$ atoms are shown as grey circles and the bonds between $\mathrm{Ca}^{2+}$ and $\mathrm{O}$ atoms of the uranyl groups are shown as dark-grey lines (all figures are modified from [12] and [13]). 
are related to the size and valence of the cations in aqueous solution. For example, divalent cations with the largest difference in ionic radii $(\mathrm{Ba}, \mathrm{Mg})$ from $\mathrm{Ca}$ in 8-coordination result in etch pits parallel to [100], whereas cations with the smallest difference in ionic radii to ${ }^{[8]} \mathrm{Ca}$ produce etch pits parallel to [010] $\left(\mathrm{Ca}, \mathrm{Sr}, \mathrm{Pb}^{2+}\right)[12,13]$.

\subsubsection{Mechanistic model for the effect of cations on the morphology of etch pits}

Schindler et al. [12] developed a model for the adsorption of cations in solution at specific surface sites on the basal surface of becquerelite. Using a protonation model for the $\mathrm{O}$-atoms on the basal surface and along its edges, they argued that adsorbed cations most likely bond to the O-atoms of the uranyl groups. They further noted that in the bulk structures of minerals of the becquerelite group, the interstitial cations bond only to O-atoms of the uranyl group or to $\left(\mathrm{H}_{2} \mathrm{O}\right)$ groups in the interlayer. As an example, they showed that $\mathrm{Ca}$ and $\mathrm{Ba}$ occur at the designated sites $\mathrm{A}$ and $\mathrm{B}$ in the interlayer of becquerelite and billietite (Fig. 4e,f). These sites are related to the distance between the apical O-atoms. Hence, the larger $\mathrm{Ba}$ atom occurs only at the A site which results in rows of Ba parallel to [100], whereas the smaller $\mathrm{Ca}$ atom occurs at the $\mathrm{A}$ and $\mathrm{B}$ sites, which results in rows of Ca parallel to [010] (Fig. 4e,f). Schindler et al. [12] showed that if adsorbed $\mathrm{Ba}$ and $\mathrm{Ca}$ adopt the same arrangement on the surface as they do in the bulk structure, they would also bond to different groups of polyhedra. Hence, adsorption of cations at these surface sites would not only prevent the formation of activated sites (through protonation) parallel to the row of cations, but it would also prevent the detachment of polyhedral groups perpendicular to the rows of cations. Using this adsorption model and the observed orientation of etch pits, Schindler et al. [12] predicted that $\mathrm{Mg}, \mathrm{Na}$ and $\mathrm{K}$ adsorb in rows parallel to [100], whereas $\mathrm{Sr}$ and $\mathrm{Pb}^{2+}$ adsorb in rows parallel to [010].

\subsubsection{Fourmarierite and Na-bearing metaschoepite}

Dissolution experiments on fourmarierite and Na-substituted metaschoepite are of particular interest because their sheets of polymerized uranyl-polyhedra are topologically identical to the sheet in schoepite $\left[\left(\mathrm{UO}_{2}\right)_{8} \mathrm{O}_{2}(\mathrm{OH})_{12}\right]\left(\mathrm{H}_{2} \mathrm{O}\right)_{12}$, and metaschoepite $\left[\left(\mathrm{UO}_{2}\right)_{4} \mathrm{O}(\mathrm{OH})_{6}\right]\left(\mathrm{H}_{2} \mathrm{O}\right)_{5}[43,44]$, both of which are present in the alteration products of oxidized primary uraninite [1].

The structures of schoepite, metaschoepite, fourmarierite and Na-substituted metaschoepite consist of anionic $\left.\left[{ }^{[7]} \mathrm{UO}_{2}\right)_{4} \mathrm{O}_{2-x}(\mathrm{OH})_{5+x}\right]^{2-x}$ sheets linked by interstitial $\mathrm{Pb}^{2+}$, $\mathrm{Na}$ or $\left(\mathrm{H}_{2} \mathrm{O}\right)$ groups (Fig. 5a [20, 43-46]). Schindler et al. [7] showed that two adjacent layers in the structures of fourmarierite and schoepite are related by a pseudo two-fold screw axis parallel to [001], and that in contrast to schoepite, the layers in fourmarierite are not shifted. Schindler et al. [8] predicted the morphology of the basal surfaces of formarierite and schoepite. Their predictions were in agreement with observations of natural crystals of fourmarierite, which elongate parallel to [100] and are terminated by [110] (Fig. 5c) and of Na-substituted metaschoepite crystals which elongate parallel to [010] and are terminated by [100] (Fig. 5d).
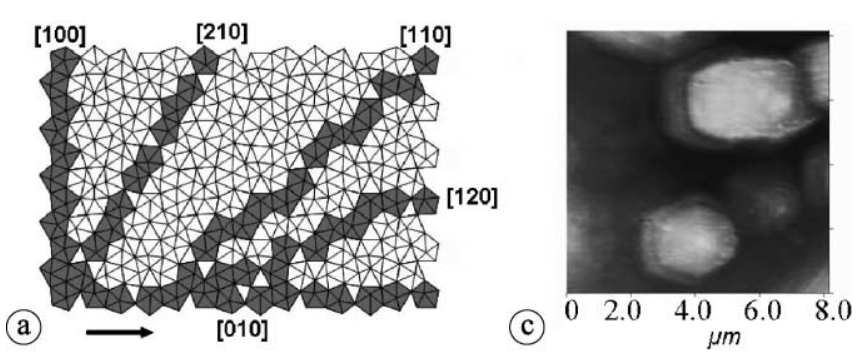

(b)
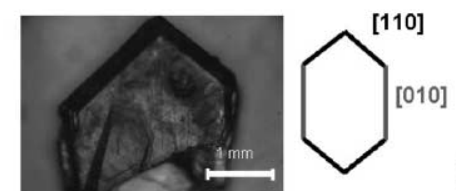

(d)

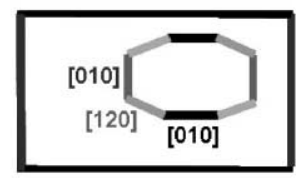

Fig. 5. (a) Polyhedron representation of the uranyl-oxide-hydroxyhydrate sheet in schoepite, metaschoepite, Na-substituted metaschoepite, and fourmarierite; polyhedron chains parallel to [100], [010], [110], [210] and [120] are highlighted in dark-grey; (b) typical morphology of fourmarierite crystals used in the dissolution experiments, and a morphological drawing of a fourmarierite crystal; (c) AFM image in height mode (false grey-tones) of etch pits formed in a $\mathrm{HCl}$-solution of pH 2 on the surface of a Na-substituted metaschoepite crystal; (d) morphology of etch pits on the surface of Na-substituted metaschoepite in relation to the morphology of the crystals.

\subsubsection{The change in morphology of etch pits}

The morphology of etch pits formed on the surface of fourmarierite and Na-substituted metaschoepite crystals treated with $\mathrm{HCl}$ solution of $\mathrm{pH} 2$ for $10 \mathrm{~min}$ reflect the morphology of their crystals. Etch pits on the surface of fourmarierite elongate parallel to [100] and are terminated by [110] edges [4]. Etch pits on the surface of Na-substituted metaschoepite elongate parallel to [010] and are defined by the edges [010], [100] and [012] (Fig. 5d), in accordance with the observed morphology of the basal surface of schoepite [8].

Fig. 6a-d and c-h shows images of etch pits formed on the surfaces of fourmarierite and Na-substituted metaschopeite in $\mathrm{K}-\mathrm{HCl}, \mathrm{Mg}-\mathrm{HCl}, \mathrm{Ca}-\mathrm{HCl}$ and $\mathrm{Ba}-\mathrm{HCl}$ solutions of
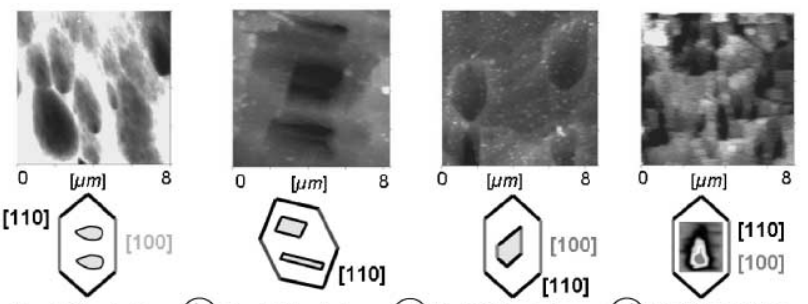

(a)
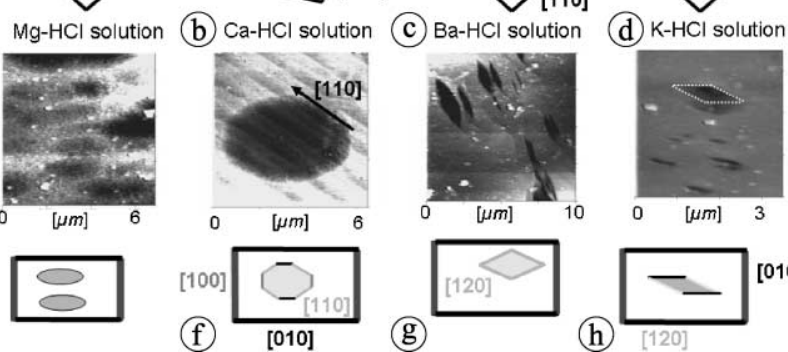

(e)

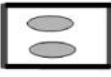

Fig. 6. AFM images in height mode of etch pits on the surface of (a-d) fourmarierite and $(\mathbf{e}-\mathbf{h}) \mathrm{Na}$-substituted metaschoepite formed in a (a, e) $\mathrm{Mg}-\mathrm{HCl}$ solution of $\mathrm{pH} 2,(\mathbf{b}, \mathbf{f}) \mathrm{Ca}-\mathrm{HCl}$ solution of $\mathrm{pH} 2$; $(\mathbf{c}, \mathbf{g}) \mathrm{Ba}-$ $\mathrm{HCl}$ solution of $\mathrm{pH} 2 ;(\mathbf{d}, \mathbf{h}) \mathrm{K}-\mathrm{HCl}$ solution of $\mathrm{pH} 2$ (a-d are modified from [14]). 
$\mathrm{pH} 2$, respectively. In the case of fourmarierite, the large mono- and divalent cations $(\mathrm{K}, \mathrm{Ba})$ result in etch pits that are parallel to the elongation of the fourmarierite crystals (Fig. 6c,d), whereas the smaller mono- and divalent cations (Mg) result in etch pits parallel to [010] (Fig. 6a). Divalent cations of intermediate size result in either more uniform etch pits $(\mathrm{Sr})$ or etch pits elongate parallel to [110] $(\mathrm{Ca})$ (Fig. 6b) [14]. For Na-substituted metaschoepite, all etch pits elongate parallel to [010], independent of the type of cation in solution.

Schindler et al. [8] showed that the shift between the layers in the structure of schoepite results in a large kink site between two adjacent layers along [ $h k 0]$ edges with $h \neq 0$. They argued that this kink site has a greater effect on crystal growth than the bond-valence deficiency of the polyhedron chains parallel to these edges, and that consequently, schoepite crystals grow parallel to the [010] edge. The elongation of etch pits on the surface of Na-substituted metaschoepite and fourmarierite shows that the shift between the layers also has a larger effect on the growth of the pits than does the type of cations in solution. However, the same cation produces similar outlines of etch pits on the surface of fourmarierite and Na-substituted metaschoepite. Etch pits with well-defined outlines form in $\mathrm{Ca}-\mathrm{HCl}$ and $\mathrm{Ba}-$ $\mathrm{HCl}$ solutions (Fig. 6b,c,f,g), whereas etch pits with rounded or irregular boundaries form in $\mathrm{Mg}-\mathrm{HCl}$ and $\mathrm{K}-\mathrm{HCl}$ solutions (Fig. 6a,d,e,h).

\subsubsection{Zippeite}

Minerals of the zippeite group occur proximal to oxidized uraninite and sulfide minerals $[6,47]$. For example, zippeite has been identified as the major U-mineral at the mine tailings sites at Key Lake, Saskatchewan, Canada (Kotzer and Schindler, pers. communication), which is part of the mining
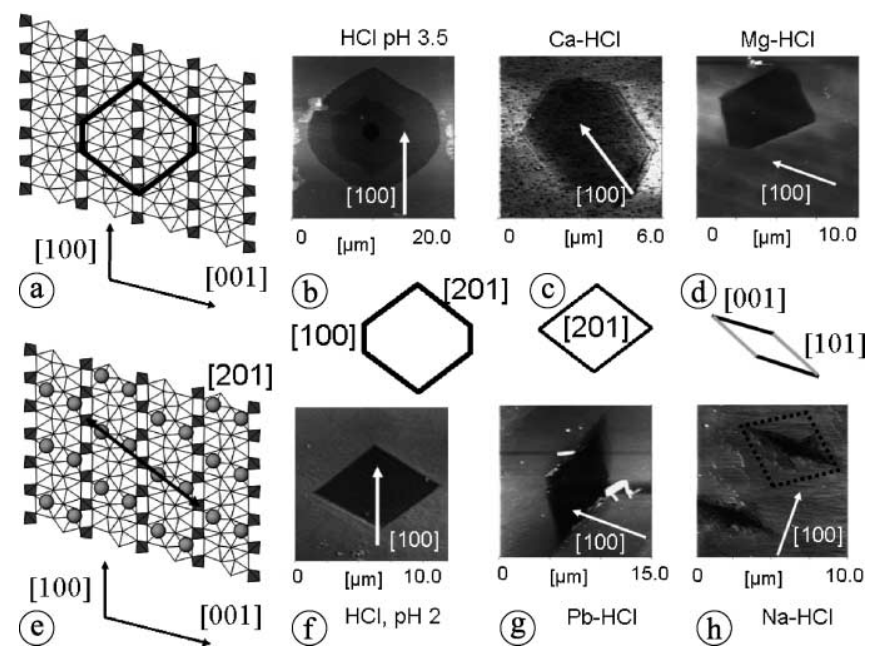

(e)

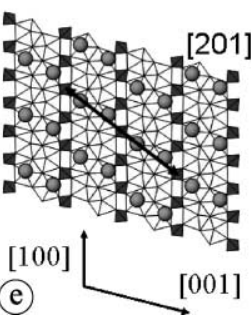

(f) $\mathrm{HCl}, \mathrm{pH}_{2}$

(g) $\mathrm{Pb}-\mathrm{HCl}$

(h) $\mathrm{Na}-\mathrm{HCl}$

Fig. 7. (a) Polyhedron representation of the uranyl-sulfate sheet in zippeite with the outline of the etch pits defined by [100] and [201] edges; (b-d) AFM images in height mode of etch pits on the surface of zippeite formed in (b) $\mathrm{HCl}$-solution of $\mathrm{pH} \mathrm{3.5,} \mathrm{(c)} \mathrm{Ca}-\mathrm{HCl}$ solution of $\mathrm{pH} 2$ and (d) $\mathrm{Mg}-\mathrm{HCl}$ solution of $\mathrm{pH} 2$; (e) polyhedron representation of the uranyl-sulfate sheet in Mg-zippeite with the location of $\mathrm{Mg}$ atoms in the interlayer shown by dark-grey circles; (f-h) AFM images in height mode of etch pits on the surface of zippeite formed in (f) $\mathrm{HCl}$-solution of $\mathrm{pH} 2$, (c) $\mathrm{Pb}-\mathrm{HCl}$ solution of $\mathrm{pH} 2$ and (d) $\mathrm{Na}-\mathrm{HCl}$ solution of $\mathrm{pH} 2$. activities along the unconformity-related uranium deposit in the Saskatchewan Basin. The structure of zippeite consists of sheets of polymerized uranyl- and sulfate polyhedra with interstitial $\mathrm{K}^{+}$and $\mathrm{H}_{2} \mathrm{O}$ (Fig. 7a,b $[17,48]$ ). The stability of an edge along the basal surface of zippeite can be estimated by calculating the bond-valence deficiency along polyhedron chains parallel to the edge (for details see [7]). For edges parallel to [201], [100] and [010], the lowest bondvalence deficiencies of the corresponding polyhedron chains are $0.19,0.23$ and $0.30 \mathrm{vu} / \AA$, respectively, indicating that stability increases in the sequence $[010]<[100]<[201]$.

\subsubsection{Morphology of etch pits}

With the exception of etch pits formed in a $\mathrm{Na}-\mathrm{HCl}$ solution of $\mathrm{pH} 2$, etch pits formed on the basal surface of zippeite in $\mathrm{HCl}$ solutions of $\mathrm{pH} 2$ and 3.5 are either defined by [201] and [100] edges (Fig. 7b-d) or exclusively by [201] edges (Fig. 7f-g). These observations are in accord with the above predictions regarding the stability of edges on the basal surface of the mineral. The occurrence of the [100] edge on surfaces treated either with a solution of higher $\mathrm{pH}(\mathrm{pH} 3.5$ vs. $\mathrm{pH} 2$ ) or a solution with cations of smaller ionic radius ( $\mathrm{Mg}$ and $\mathrm{Ca} v$ s. $\mathrm{Pb}$ ) suggests that $\mathrm{pH}$ (i.e. the rate of dissolution) and the size of the cation in solution affect the stability of the latter edge.

Fig. 7e shows the arrangement of interstitial Mg between the layers of $\mathrm{Mg}$-zippeite [17]. The cations are arranged in rows parallel to [201], indicating that similar arrangements of adsorbed cation species on the surface of zippeite promote the stability of the latter edge. Etch pits formed in an $\mathrm{Na}-\mathrm{HCl}$ solution of $\mathrm{pH} 2$ are elongated perpendicular to [100] and are defined by the edges [001] and [101] (Fig. 7h). The latter morphology suggests that adsorbed $\mathrm{Na}$ is arranged differently than $\mathrm{Mg}, \mathrm{Ca}$ and $\mathrm{Pb}$ on the surface of zippeite. Similarly, interstitial $\mathrm{Na}$ in Na-zippeite is arranged differently than interstitial $\mathrm{Mg}$ in $\mathrm{Mg}$-zippeite [17].

\subsubsection{Conclusions regarding the change in etch pit morphology with the type of cation in solution}

Dissolution experiments of becquerelite, billietite, Nasubstituted metaschoepite, fourmarierite, and zippeite in different electrolyte solutions show that adsorbed cations can affect the orientation and morphology of etch pits on the basal surface of these minerals. Based on experiments using becquerelite and billietite, the arrangement of adsorbed cation species on the surface of uranyl minerals can be predicted once one knows the effect of size and charge of a cation in solution on the growth of an etch pit. However, dissolution experiments on Na-substituted metaschoepite and fourmarierite show that the structural arrangement of sheets with identical topology can have a larger effect on dissolution mechanisms than the arrangement of adsorbed cations; a situation that does not allow prediction of the arrangement of adsorbed cations.

\subsection{Dissolution-precipitation processes on the surface of uranyl-minerals}

Dissolution experiments in solutions under weak acidic $(\mathrm{pH}=3.5)$, neutral (distilled water) and basic conditions 
$(\mathrm{pH}=10.5)$ resulted in the formation of secondary precipitates on the surface of almost all uranyl minerals. Silica- and sulfate-rich precipitates also form in electrolyte solutions of $\mathrm{pH} 2$ on the surfaces of uranophane and zippeite, respectively. These precipitates formed thin surface coatings that were often only detectable with AFM and XPS. Hence, non-surface sensitive instruments such as SEM or Electron Microprobe could not give any information on the occurrence or composition of these surface coatings.

Here, we describe a variety of different surface coatings that may form over the course of dissolution of various uranyl minerals under different dissolution conditions. We will review the results on their AFM examination, present new XPS data on their chemical composition and discuss their relevance in terms of weathering processes on uranyl minerals. We will finally show how the formation of different coatings on the surface of uranyl minerals can be monitored (not identified) with the proportions of the major elements and the bands in the $\mathrm{O} 1 s$ spectra.

\subsubsection{Environmental relevance of surface coatings}

When a mineral weathers, dissolution and (secondary) precipitation may be coupled. Such coupled dissolutionprecipitation processes may result in nanometer thick coatings that can alter surface reactivity with respect to processes such as additional dissolution and adsorption reactions. For example, nanometer thick coatings on the surface of altered silicate minerals may affect the solubility and dissolution rate of the underlying minerals $[49,50]$.

\subsubsection{Uranyl-hydroxy-hydrate precipitation without any additional cations and anions}

Dissolution experiments in ultrapure water resulted in the formation of growth hillocks on the surfaces of all uranyl minerals examined. Hillocks were also observed on the surfaces of becquerelite, fourmarierite and uranophane after treatment with an $\mathrm{HCl}$-solution of $\mathrm{pH} 3.5$. The rounded hillocks commonly have lateral dimensions $\sim 0.5 \times 0.5 \mu \mathrm{m}$, and individual hillocks have a maximum height of $\sim 70 \mathrm{~nm}$ (Fig. 8a). XPS studies on uranophane [15], becquerelite, billietite and zippeite crystals (this study) show that their surfaces are enriched in $\mathrm{U}$ and $\mathrm{O}$ relative to all other elements, indicating that the hillocks on the surface of these minerals are part of a highly-hydrated U-rich phase (Table 3). Hillocks similar to those observed on the surface of uranyl minerals were also found on the surface of calcite after interaction with a uranyl-acetate solution of $\mathrm{pH} 4.5$ [9]. The authors identified the corresponding precipitate as schoepite, $\left[\left(\mathrm{UO}_{2}\right)_{8} \mathrm{O}_{2}(\mathrm{OH})_{12}\right]\left(\mathrm{H}_{2} \mathrm{O}\right)_{12}$, together with a large amount of $\mathrm{X}$-ray amorphous material.

The occurrence of a schoepite-type phase on the basal surface of a uranyl mineral can be verified through inspection of the binding energy of the $\mathrm{U}^{6+}$ band in the U $4 f$ XPS spectrum. Schindler et al. [27] showed that the $\mathrm{U}^{6+}$ band in spectra of uranyl-hydroxy-hydrate minerals without interstitial cations (metaschoepite, $\left[\left(\mathrm{UO}_{2}\right)(\mathrm{OH})_{2}\right]-\alpha$, and $-\beta$ ) occurs at $382.0-382.3 \mathrm{eV}$, whereas the $\mathrm{U}^{6+}$ band for uranylhydroxy-hydrate minerals with divalent cations (becquere-

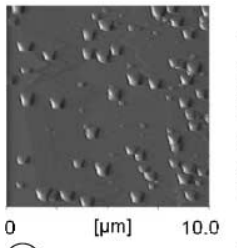

(a)

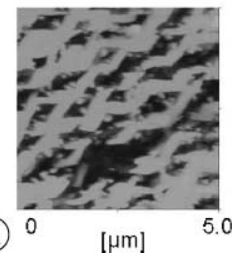

(d)

Fig. 8. (a) AFM image in deflection mode of hillocks formed in ultrapure water on the surface of Na-substituted metaschoepite; (b) the $\mathrm{O}=\mathrm{U}=\mathrm{O}: \mathrm{U}-\mathrm{O}-\mathrm{U}$ ratio as a function of the $\mathrm{O}: \mathrm{U}$ ratio on surfaces of billietite and becquerelite crystals treated with different solutions (see Table 3 for details); triangles indicate becquerelite samples, spheres indicate billietite samples, squares indicate billietite and becquerelite surfaces treated with $\mathrm{Na}_{2} \mathrm{CO}_{3}$ solutions, diamond and inverted triangle surfaces treated with deionized water; labels bill becq stand for billietite and becquerelite; (c-d) AFM images in deflection and height mode of growth hillocks and a striped pattern of hillocks on the basal surfaces of becquerelite and billeitite crystals treated with a $0.1 \mathrm{~mol} \mathrm{~L}^{-1} \mathrm{Na}_{2} \mathrm{CO}_{3}$ of $\mathrm{pH} 10.5$, respectively; (e) AFM image in deflection mode of elongated hillocks on the surface of fourmarierite with a $0.1 \mathrm{~mol} \mathrm{~L}^{-1} \mathrm{Na}_{2} \mathrm{CO}_{3}$ of $\mathrm{pH} 10.5$; (f) AFM image in deflection mode of small crystallites formed in a $\mathrm{Pb}-\mathrm{HCl}$ solution of $\mathrm{pH} 2$ on the surface of uranophane (d, e and $\mathbf{f}$ are modified from [13-15]).
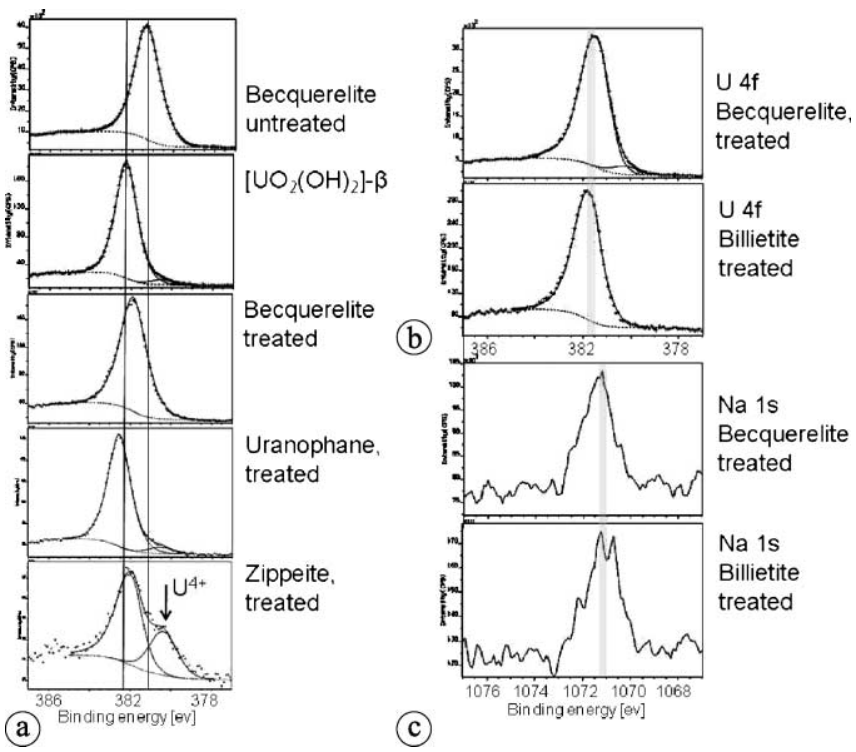

Fig. 9. (a) U $4 f$ spectra taken from untreated surfaces of becquerelite and $\left[\left(\mathrm{UO}_{2}\right)(\mathrm{OH})_{2}\right]-\beta$ and from becquerelite, zippeite and uranophane surfaces treated with deionized water (see labels); vertical lines indicate the location of the $\mathrm{U}^{6+}$ bands in the spectra for the untreated surfaces; (b) U $4 f$ spectra and (c) $\mathrm{Na} 1 s$ spectra of becquerelite and billietite surfaces treated with a $\mathrm{Na}_{2} \mathrm{CO}_{3}$ solution of $\mathrm{pH} 10.5$.

lite, billietite and fourmarierite) occurs at 381.1-381.6 eV (Fig. 9a,b). Fig. 9a shows U $4 f$ spectra of untreated crystals of becquerelite and $\left[\left(\mathrm{UO}_{2}\right)(\mathrm{OH})_{2}\right]-\beta$, and crystals of becquerelite, uranophane and zippeite after treatment with ultrapure water. Closer inspection of the latter spectra indicates that 
Table 3. Chemical composition of treated surfaces of becquerelite and billietite.

\begin{tabular}{|c|c|c|c|c|}
\hline $\begin{array}{l}\text { Becquerelites } \\
\text { treated with }\end{array}$ & $\mathrm{U}: \mathrm{Ca}$ & $\mathrm{U}: \mathrm{Na}$ & $\mathrm{O}: \mathrm{U}$ & $\begin{array}{l}\mathrm{O}=\mathrm{U}=\mathrm{O}: \\
\mathrm{U}-\mathrm{O}-\mathrm{U}\end{array}$ \\
\hline Untreated & $3.0(1)$ & & $5.2(1)$ & $1.6(2)$ \\
\hline Untreated & $3.0(1)$ & & $6.0(1)$ & $1.6(2)$ \\
\hline Deionized water & $16.9(1)$ & & $13.0(1)$ & $3.9(2)$ \\
\hline $\mathrm{HCl}, \mathrm{pH}=3.5$ & $6.0(1)$ & & $6.4(1)$ & $2.4(2)$ \\
\hline $\mathrm{HCl}, \mathrm{pH}=3.5$ & $6.2(1)$ & & $7.3(1)$ & $2.9(2)$ \\
\hline $\mathrm{K}-\mathrm{HCl}, \mathrm{pH}=2$ & $5.3(1)$ & & $7.8(1)$ & $3.2(2)$ \\
\hline $\mathrm{Mg}-\mathrm{HCl}, \mathrm{pH}=2$ & $22.0(1)$ & & $7.3(1)$ & $3.3(2)$ \\
\hline $\mathrm{Na}-\mathrm{HCl}, \mathrm{pH}=2$ & $12.6(1)$ & n.d. ${ }^{a}$ & $5.8(1)$ & $2.4(2)$ \\
\hline $\mathrm{Na}_{2} \mathrm{CO}_{3}, \mathrm{pH}=10.5$ & $4.9(1)$ & $3.0(1)$ & $5.6(1)$ & $1.6(2)$ \\
\hline $\mathrm{Na}_{2} \mathrm{CO}_{3}, \mathrm{pH}=10.5$ & $7.0(1)$ & $2.0(1)$ & $7.2(1)$ & $1.8(2)$ \\
\hline $\begin{array}{l}\text { Billietites } \\
\text { treated with }\end{array}$ & $\mathrm{U}: \mathrm{Ba}$ & $\mathrm{U}: \mathrm{Na}$ & $\mathrm{O}: \mathrm{U}$ & $\begin{array}{l}\mathrm{O}=\mathrm{U}=\mathrm{O} \\
\mathrm{U}-\mathrm{O}-\mathrm{U}\end{array}$ \\
\hline Untreated & $4.0(1)$ & & $4.5(1)$ & $2.2(2)$ \\
\hline Deionized water & n.d. ${ }^{a}$ & & $9.4(1)$ & $3.6(2)$ \\
\hline $\mathrm{HCl}, \mathrm{pH}=3.5$ & n.d. ${ }^{a}$ & & $5.6(1)$ & $3.4(2)$ \\
\hline $\mathrm{Mg}-\mathrm{HCl}, \mathrm{pH}=2$ & $6.0(1)$ & & $5.2(1)$ & $3.0(2)$ \\
\hline $\mathrm{Sr}-\mathrm{HCl}, \mathrm{pH}=2$ & $5.0(1)$ & & $4.8(1)$ & $3.0(2)$ \\
\hline $\mathrm{Ca}-\mathrm{HCl}, \mathrm{pH}=2$ & n.d. ${ }^{a}$ & & $4.5(1)$ & $2.2(2)$ \\
\hline $\mathrm{Na}_{2} \mathrm{CO}_{3}, \mathrm{pH}=10.5$ & n.d. ${ }^{a}$ & $1.6(1)$ & $6.9(1)$ & $2.0(2)$ \\
\hline
\end{tabular}

a: n.d.: Peaks in Na $1 s$ and Ba $3 d$ spectra were below background.

(1) The $\mathrm{U}^{6+}$ band for the treated surface of becquerelite has shifted to higher binding energies;

(2) The $\mathrm{U}^{6+}$ bands for the treated surfaces of uranophane and zippeite occur at higher or similar binding energies than the band in the spectrum for $\left[\left(\mathrm{UO}_{2}\right)(\mathrm{OH})_{2}\right]-\beta$;

(3) Only the $U 4 f_{7 / 2}$ spectrum for zippeite contains a significant proportion of the $\mathrm{U}^{4+}$ band.

These binding energies, in combination with observed depletion of the surface with respect to the interstitial cation clearly demonstrate the presence of a schoepite-type phase on the surfaces of the treated crystals.

Determination of the chemical composition of a solution after treatment of a uranophane crystal with an $\mathrm{HCl}$ solution of $\mathrm{pH} 3.5$ showed that the solution was undersaturated with respect to schoepite, although hillocks of a U-rich phase were observed on the basal surface [15]. As a result, the authors concluded that the hillocks are part of an amorphous schoepite-type phase rather than schoepite itself.

\subsubsection{Na-uranyl-hydroxy-hydrate precipitates}

Dissolution experiments with a $\mathrm{Na}_{2} \mathrm{CO}_{3}$ solution of $\mathrm{pH} 10.5$ produce growth hillocks on the surfaces of becquerelite, billietite and fourmarierite, although the appearance of the hillocks varies from mineral to mineral. For example, rounded hillocks occur on the surface of becquerelite and uranophane (Fig. 8c [12]), striped patterns of steps occur on the surface of billietite (Fig. 8d [13]), and elongated hillocks on the surface of fourmarierite (Fig. 8e [14]).

XPS analysis showed that the reacted surfaces are enriched in $\mathrm{U}$ and $\mathrm{Na}$ relative to the untreated surfaces (Table 3). Inspection of the binding energy of the $U 4 f_{7 / 2}$ spectra for becquerelite and billietite surfaces treated with a $\mathrm{Na}_{2} \mathrm{CO}_{3}$ solution indicates that the corresponding $\mathrm{U}^{6+}$ bands occur at similar binding energies (381.6-381.8,
Fig. 9b). Furthermore, the peaks in the $\mathrm{Na} 1 \mathrm{~s}$ spectra for both surfaces occur at similar binding energies (1071.1$1071.4 \mathrm{eV}$, Fig. 9c), which differ for example from binding energies observed in $\mathrm{Na} 1 s$ spectra for $\mathrm{Na}$-bearing zeolites ( $>1072 \mathrm{eV},[30])$. These similar binding energies for the $\mathrm{U}^{6+}$ bands and the $\mathrm{Na} 1 s$ peaks suggest that $\mathrm{U}$ and $\mathrm{Na}$ occur in similar chemical environments in Na-U-bearing phases on the surfaces of becquerelite and billietite. Furthermore, FTIR [13] and XPS analyses did not indicate the presence of $\left(\mathrm{CO}_{3}\right)^{2-}$ on the surfaces, ruling out the presence of a Na-uranyl-carbonate phase on the surfaces of the uranylhydroxy-hydrates.

Potential phases could be clarkeite, $\mathrm{Na}\left[\left(\mathrm{UO}_{2}\right) \mathrm{O}(\mathrm{OH})\right]$ $\mathrm{H}_{2} \mathrm{O}$ and $\mathrm{Na}_{2}\left[\left(\mathrm{UO}_{2}\right)_{3} \mathrm{O}_{3}(\mathrm{OH})_{2}\right]$ [51,52]. The latter phase was synthesized under hydrothermal conditions, whereas the former phase can precipitate from ambient solutions at neutral and high $\mathrm{pH}$ and with high and low concentrations of $\mathrm{Na}[53,54]$. Giammar and Hering [53] showed that metaschoepite transforms into a clarkeite-type phase in the presence of $\mathrm{Na}$ ions in solution. The authors showed that the formation of the clarkeite-type phase reduced the dissolved equilibrium concentration of uranium by 2 orders of magnitude. This result suggests that the observed Na-U-bearing coating on the surface of becquerelite, billietite, and fourmarierite can indeed alter the solubility of these phases with respect to a Na-bearing solution of high $\mathrm{pH}$.

\subsubsection{Na-uranyl-carbonate precipitates}

Fig. 10e shows a striped pattern of steps on the surface of zippeite treated with a $\mathrm{Na}_{2} \mathrm{CO}_{3}$ solution of $\mathrm{pH} 10.5$. The
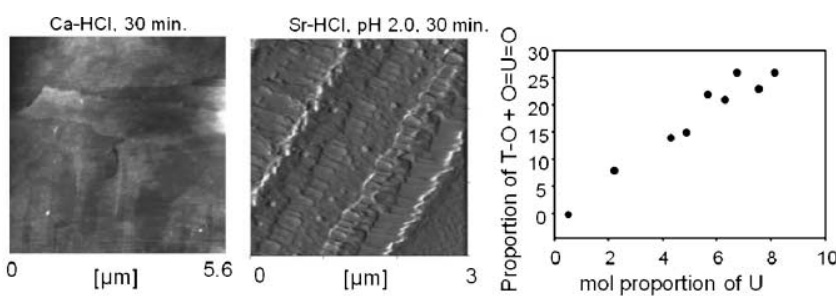

(a) $\mathrm{Ba}-\mathrm{HCl} .30 \mathrm{~min}$ (b)

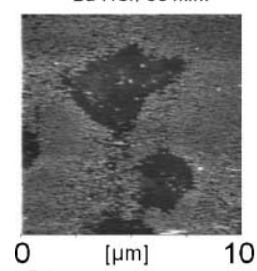

(d)

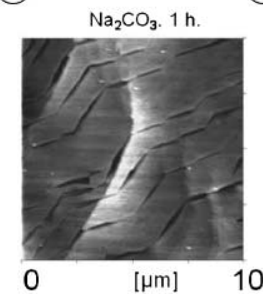

(c)

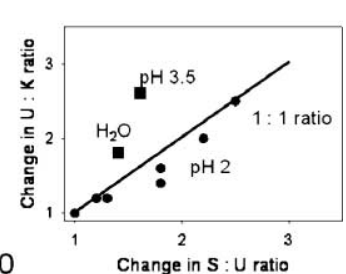

(f)

Fig. 10. (a) AFM image in height mode of a coating formed after $30 \mathrm{~min}$ in a $\mathrm{Ca}-\mathrm{HCl}$ solution of $\mathrm{pH} 2$ on the surface of uranophane; (b) AFM image in deflection mode showing the occurrence of wellorientated hillocks formed after $30 \mathrm{~min}$ in a $\mathrm{SrCl}_{2}-\mathrm{HCl}$ solution of $\mathrm{pH} 2$; (c) the proportions of $\mathrm{O}=\mathrm{U}=\mathrm{O}+\mathrm{T}-\mathrm{O}$ as a function of the mole proportions of $\mathrm{U}$ on untreated and treated basal surfaces of uranophane; (d) AFM image in height mode of hillocks formed in $\mathrm{Ba}-\mathrm{HCl}$ solution of $\mathrm{pH} 2$ on the surface of zippeite; (e) AFM image in deflection mode of a striped pattern of steps of a Na- $\left(\mathrm{UO}_{2}\right)^{2+}$-carbonatesulfate phase formed in an aqueous $\mathrm{Na}_{2} \mathrm{CO}_{3}$ solution of $\mathrm{pH} 10.5$ on the surface of zippeite; (f) change in $\mathrm{U}: \mathrm{K}$ ratio as a function of the change in $\mathrm{S}: \mathrm{U}$ for surfaces of zippeite treated with different solutions (both parameters are given in relation to the untreated surface and the $1: 1$ ratio between both parameters is indicated with a solid line, see text for details); (a-c) are modified from [15]. 
Table 4. Chemical composition of treated surfaces of zippeite, $\mathrm{K}_{3}\left(\mathrm{H}_{2} \mathrm{O}\right)_{3}\left[\left(\mathrm{UO}_{2}\right)_{4}\left(\mathrm{SO}_{4}\right)_{2} \mathrm{O}_{3}(\mathrm{OH})\right]$.

\begin{tabular}{|c|c|c|c|}
\hline \multirow{2}{*}{$\begin{array}{l}\text { Treatment } \\
\text { Bulk composition }\end{array}$} & \multicolumn{2}{|c|}{$\begin{array}{c}\text { Change in } \mathrm{S}: \mathrm{U} \text { ratio Change in } \mathrm{U}: \mathrm{K} \text { ratio } \\
\text { Changes in ratio are given with respect } \\
\text { to bulk composition }\end{array}$} & \multirow[t]{2}{*}{$\begin{array}{l}\mathrm{M}: \mathrm{U} \text { ratio } \\
\mathrm{M}=\mathrm{Ca}, \mathrm{Sr} \\
\mathrm{Pb}, \mathrm{Na}\end{array}$} \\
\hline & $1.0(1)$ & $1.0(1)$ & \\
\hline Untreated surface & $1.2(1)$ & $1.2(1)$ & \\
\hline Ultrapure water & $0.6(1)$ & $1.7(1)$ & \\
\hline $\mathrm{HCl}, \mathrm{pH}=3.5$ & $1.6(1)$ & $2.6(1)$ & \\
\hline $\mathrm{HCl}, \mathrm{pH}=2$ & $1.3(1)$ & $1.2(1)$ & \\
\hline $\mathrm{Ba}-\mathrm{HCl}, \mathrm{pH}=2$ & $2.1(1)$ & n.d. ${ }^{a}$ & $1.3(1)$ \\
\hline $\mathrm{Sr}-\mathrm{HCl}, \mathrm{pH}=2$ & $1.4(1)$ & $1.8(1)$ & $0.4(1)$ \\
\hline $\mathrm{Pb}-\mathrm{HCl}, \mathrm{pH}=2$ & $2.5(1)$ & $2.5(1)$ & $0.08(10)$ \\
\hline $\mathrm{Ca}-\mathrm{HCl}, \mathrm{pH}=2$ & $1.8(1)$ & $1.4(1)$ & n.d. ${ }^{a}$ \\
\hline $\mathrm{Mg}-\mathrm{HCl}, \mathrm{pH}=2$ & $2.2(1)$ & $2.0(1)$ & n.d. ${ }^{a}$ \\
\hline $\mathrm{Na}_{2} \mathrm{CO}_{3}, \mathrm{pH}=10.5$ & $1.6(1)$ & $1.6(1)$ & $1.5(1)$ \\
\hline
\end{tabular}

a: n.d.: Peaks in $\mathrm{K} 2 p, \mathrm{Ca} 2 p$ and $\mathrm{Mg} 2 p$ spectra were below background.

corresponding $\mathrm{C} 1 s$ spectrum shows a well-defined peak at circa $289 \mathrm{eV}$, indicating the presence of $\left(\mathrm{CO}_{3}\right)^{2-}$ groups on the treated surface. The XPS data further indicates $\mathrm{C}: \mathrm{U}$ and $\mathrm{Na}: U$ ratios of $3: 1$ and $2: 1$, respectively, and an increase in the $S: U$ and $U: K$ ratios with respect to the untreated surface of zippeite (Table 4).

These atomic ratios suggest that the step pattern is part of a Na-uranyl-carbonate precipitate, although it is unclear whether the increase in the $\mathrm{S}: \mathrm{U}$ ratio is a product of the incorporation of $\left(\mathrm{SO}_{4}\right)^{2-}$ groups into the precipitate (see below) or an alteration of the underlying zippeite surface.

Potential phases could be phases structurally related to cejkaite, $\mathrm{Na}_{4}\left[\left(\mathrm{UO}_{2}\right)\left(\mathrm{CO}_{3}\right)_{3}\right]$ [55], synthetic $\mathrm{Na}_{4}\left[\left(\mathrm{UO}_{2}\right)\right.$ $\left.\left(\mathrm{CO}_{3}\right)_{3}\right]$ [56], grimselite, $\mathrm{K}_{3} \mathrm{Na}\left[\left(\mathrm{UO}_{2}\right)\left(\mathrm{CO}_{3}\right)_{3}\right]\left(\mathrm{H}_{2} \mathrm{O}\right)$ [57] and schröckeringite, $\mathrm{NaCa}_{3}\left[\left(\mathrm{UO}_{2}\right)\left(\mathrm{CO}_{3}\right)_{3}\right] \mathrm{F}\left(\mathrm{H}_{2} \mathrm{O}\right)_{10}$ [58]. The structures of these phases contain the prominent uranyltricarbonate cluster, $\left[\left(\mathrm{UO}_{2}\right)\left(\mathrm{CO}_{3}\right)_{3}\right]^{4-}$, which is the dominant uranyl aqueous-species at high $\mathrm{pH}$ [22]. The clusters are usually connected by interstitial cations ( $\mathrm{Na}, \mathrm{Ca}, \mathrm{K})$, anions $\left(\mathrm{F}-,\left(\mathrm{SO}_{4}\right)^{2-}\right.$ and $\mathrm{H}_{2} \mathrm{O}$ groups. As pointed out by $\mathrm{Li}$ et al. [57], synthetic $\mathrm{Na}_{4}\left[\left(\mathrm{UO}_{2}\right)\left(\mathrm{CO}_{3}\right)_{3}\right]$ and schröckeringite $\mathrm{NaCa}_{3}\left[\left(\mathrm{UO}_{2}\right)\left(\mathrm{CO}_{3}\right)_{3}\right]\left(\mathrm{SO}_{4}\right) \mathrm{F}\left(\mathrm{H}_{2} \mathrm{O}\right)$ are more closely related to each other than to other uranyl-tricarbonate minerals as they are composed of sheets of polymerized $\mathrm{M}_{3} \phi_{n}$ trimers $(\mathrm{M}=\mathrm{Ca}, \mathrm{Na}, \phi=$ undefined ligand $)$ and uranyl-tricarbonate clusters.

The question arises as to why a uranyl-tricarbonate phase has not been observed on the surfaces of the uranylhydroxy-hydrates treated with $\mathrm{Na}_{2} \mathrm{CO}_{3}$ solutions of $\mathrm{pH} 10.5$ (see above). A possible answer to this question could be the presence of $\left(\mathrm{SO}_{4}\right)^{2-}$ groups during the dissolutionprecipitation process on the surface of zippeite. These groups may have promoted the formation of a uranyltricarbonate phase structurally related to schröckeringite, $\mathrm{NaCa}_{3}\left[\left(\mathrm{UO}_{2}\right)\left(\mathrm{CO}_{3}\right)_{3}\right]\left(\mathrm{SO}_{4}\right) \mathrm{F}\left(\mathrm{H}_{2} \mathrm{O}\right)_{10}$, at the interface between the mineral surface and the solution. This conclusion is in accord with the observed increase in the $\mathrm{S}: \mathrm{U}$ ratio on the surface of zippeite, because the precipitation of a schröckeringite-type phase $(S: U$ ratio $=1: 1)$ would result in an increase in $\mathrm{S}: \mathrm{U}$ with respect to the untreated surface of zippeite $(\mathrm{S}: \mathrm{U}$ ratio $=1: 2)$.

\subsubsection{Ba and Pb-bearing uranyl-hydroxy-hydrate precipitates}

Small crystallites of a $\mathrm{Ba}$ and $\mathrm{Pb}$-bearing uranyl-hydroxyhydrate phase were identified on the basal surface of uranophane after treatment with aqueous $\mathrm{Pb}\left(\mathrm{NO}_{3}\right)_{2}-\mathrm{HCl}$ and $\mathrm{BaCl}_{2}-\mathrm{HCl}$ solutions of $\mathrm{pH} 2$ [15]. The formation of billietite on the surface of uranophane is supported by the. morphological features of the $\mathrm{Pb}$ - and $\mathrm{Ba}$-containing crystallites (Fig. 8f), an increase in the molar ratios $\mathrm{Ba}: \mathrm{Si}$ and $\mathrm{U}: \mathrm{Si}$ with the duration of the $\mathrm{Ba}-\mathrm{HCl}$ experiment, and the occurrence of an additional band in the corresponding $\mathrm{O} 1 s$ spectra. The $\mathrm{Pb}$-bearing crystallites may also represent a uranyl-hydroxy-hydrate phase, since $\mathrm{Pb}$ bearing uranyl-hydroxy-hydrate minerals have a lower solubility than other alkaline-earth-bearing uranyl-hydroxy-hydrate phases [16].

\subsubsection{Amorphous silica precipitates}

Si-rich coatings were observed on the basal surface of uranophane after treatment with acidic solutions of $\mathrm{pH} 2$. The thickness of the Si-rich coatings varies with the type of cation in solution, and the appearance and adhesive nature of the coating varies with the time span between dissolution and characterization by AFM [15]. For example, a thin surface coating $(\sim 2 \mathrm{~nm})$ formed in a $\mathrm{CaCl}_{2}-\mathrm{HCl}$ solution of pH 2 (Fig. 10a), and a thick continuous coating (micrometer scale) was observed after treatment with a $\mathrm{Mg}-\mathrm{HCl}$ solution of $\mathrm{pH}$ 2. Si-rich hillocks occurred on the surface after treatment with a $\mathrm{SrCl}_{2}-\mathrm{HCl}$ solution (Fig. 10b). Examinations of the $\mathrm{Si} 2 p$ and $\mathrm{O} 1 s$ spectra for these coatings showed that:

(1) The coatings formed in $\mathrm{Mg}-\mathrm{HCl}$ and $\mathrm{Ca}-\mathrm{HCl}$ solutions are structurally and chemically similar to the silicagel-type-coatings $\left(\mathrm{H}_{4} \mathrm{SiO}_{4}\left(\mathrm{H}_{2} \mathrm{O}\right)_{n}\right)$ on the surface of feldspars [59] and

(2) The hillocks observed three days after treatment in a $\mathrm{SrCl}_{2}-\mathrm{HCl}$ solution of $\mathrm{pH} 2$ have a composition of $\left(\mathrm{H}_{2} \mathrm{SiO}_{3}\right.$ or $\left.\mathrm{Si}_{2} \mathrm{O}_{2}(\mathrm{OH})_{4}\right)$.

The latter composition indicates an average polymerization degree of a chain as consequence of an aging process of the hydrous silica coating [15]. 


\subsubsection{Sulfate precipitates}

Fig. 10d shows small hillocks covering almost completely the surface of a zippeite crystal treated with a $\mathrm{Ba}-\mathrm{HCl}$ solution of $\mathrm{pH}$ 2. XPS studies indicate that the hillocks are part of a Ba- $\left(\mathrm{UO}_{2}\right)^{2+}$-sulfate precipitate for which the sum of the atomic proportions for $\mathrm{Ba}^{2+}$ and $\left(\mathrm{UO}_{2}\right)^{2+}$ is approximately equal to the atomic proportion for $\mathrm{S}$ (i.e. $\left.\mathrm{Ba}_{1.2}\left(\mathrm{UO}_{2}\right)_{0.8}\left(\mathrm{SO}_{4}\right)_{2}\right)$. A potential phase could be a baritetype phase in which some of $\mathrm{Ba}^{2+}$ is replaced by $\left(\mathrm{UO}_{2}\right)^{2+}$.

Precipitations with the composition $\mathrm{M}_{x}\left(\mathrm{UO}_{2}\right)_{2-x}\left(\mathrm{SO}_{4}\right)_{2}$ $(\mathrm{M}=\mathrm{Sr}, \mathrm{Pb})$ also occur on zippeite surfaces treated with $\mathrm{Sr}-\mathrm{HCl}$ and $\mathrm{Pb}-\mathrm{HCl}$ solutions of $\mathrm{pH} 2$. The surfaces contain a lower density of growth hillocks and lower $\mathrm{M}$ : $\mathrm{U}$ ratios $\left(\mathrm{M}=\mathrm{Ba}, \mathrm{Sr}\right.$ and $\mathrm{Pb}^{2+}$, Table 4$)$ than the surface treated with a $\mathrm{Ba}-\mathrm{HCl}$ solution, suggesting that the density of growth hillocks on the treated zippeite surfaces correlate with the corresponding $\mathrm{M}: \mathrm{U}$ ratio.

\subsection{Monitoring the change in surface composition and structure}

Schindler et al. [15] showed that the change in surface composition and structure of treated crystals can be monitored with the proportions of the major elements and the bands in the $\mathrm{O} 1 s$ spectra.

\subsubsection{Becquerelite and Billietite}

Dissolution processes can produce a higher number of kink sites with protonated $\left(\mathrm{U}-\mathrm{OH}\right.$ and $\left.\mathrm{U}-\mathrm{OH}_{2}\right)$ or unprotonated ( $\mathrm{U}-\mathrm{O}-\mathrm{U}$ and $\mathrm{U}-\mathrm{O}$ ) surface terminations, which results commonly in a higher ratio between $\mathrm{O}$ and $\mathrm{U}$. Dissolutionprecipitation processes yield to the formation of hydrous surface coatings that contain a high number of adsorbed $\mathrm{H}_{2} \mathrm{O}$ species and may result in an increase in the number of kink sites (depending on the type of growth phenomena; i.e. step-, spiral or two-dimensional growth). Hence, the ratio between the surface species $\mathrm{H}_{2} \mathrm{O}_{\text {interst }}, \mathrm{OH}, \mathrm{O}=\mathrm{U}=\mathrm{O}$ and $\mathrm{O}-\mathrm{U}-\mathrm{O}$ should change with the degree of dissolution or the type of surface precipitation.

Schindler et al. [28] showed that contributions of Obearing carbon species $(\mathrm{C}-\mathrm{O})$ from the underlying carbon tape or adventitious carbon species affect the proportion of the bands $\mathrm{H}_{2} \mathrm{O}_{\text {interst }}$ and $\mathrm{OH}$. They also showed that these contributions could be calculated using the proportion of the $\mathrm{C}-\mathrm{O}$ bands in the $\mathrm{C} 1 s$ spectrum and the $\mathrm{C}: \mathrm{O}$ ratio on the surface. However, these calculations and the associated uncertainties with respect to fitting and assignment of $\mathrm{C}-\mathrm{O}$ bands can be avoided, if one only considers the proportions of the bands $\mathrm{O}=\mathrm{U}=\mathrm{O}$ and $\mathrm{O}-\mathrm{U}-\mathrm{O}$.

The $\mathrm{O}=\mathrm{U}=\mathrm{O}$ species cannot be protonated during a dissolution process in an acidic solution (violation of the valence-sum rule), whereas protonation of equatorial $\mathrm{O}$ atoms results in a decrease in the proportion of $\mathrm{U}-\mathrm{O}-\mathrm{U}$. Hence, the $\mathrm{O}=\mathrm{U}=\mathrm{O}: \mathrm{U}-\mathrm{O}-\mathrm{U}$ ratio increases during the treatment with an acidic solution and can be used to monitor the degree of dissolution on a basal surface. The number of kink sites or adsorbed $\mathrm{H}_{2} \mathrm{O}$ species can be monitored with the change in the $\mathrm{O}: \mathrm{U}$ ratio [28].

Fig. 11 shows $\mathrm{O} 1 \mathrm{~s}$ spectra of untreated and treated surfaces of becquerelite. The bands below the maximum at circa $381 \mathrm{eV}$, and shoulder at circa $530 \mathrm{eV}$ (indicated with an ar-

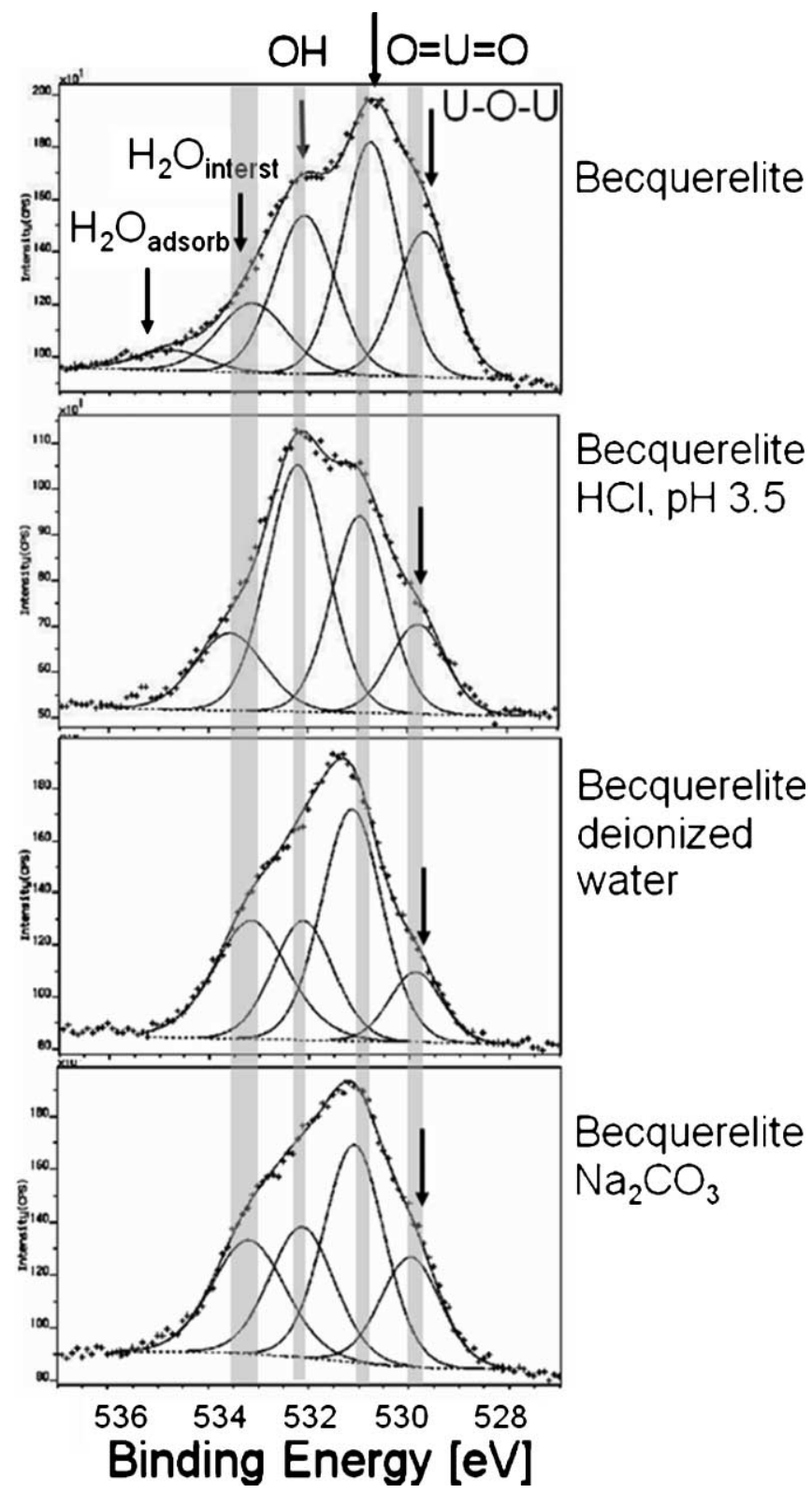

Fig. 11. (a) $\mathrm{O} 1 \mathrm{~s}$ spectra of an untreated surface of becquerelite and of becquerelite surfaces treated with a $\mathrm{HCl}$-solution of $\mathrm{pH} 3.5$, deionized water and a $\mathrm{Na}_{2} \mathrm{CO}_{3}$ solution of $\mathrm{pH} 10.5$; vertical grey bars and arrows indicate the location of the bands $\mathrm{U}-\mathrm{O}-\mathrm{U}, \mathrm{O}=\mathrm{U}=\mathrm{O}, \mathrm{OH}$ and $\mathrm{H}_{2} \mathrm{O}_{\text {interst }}$; additional arrows indicate shoulders at the lower bindingenergy side of the $\mathrm{U} 4 f$ envelopes.

row), represent the species $\mathrm{O}=\mathrm{U}=\mathrm{O}$ and $\mathrm{U}-\mathrm{O}-\mathrm{U}$, respectively. The ratio between the intensities at the maxima and shoulders vary from spectrum to spectrum and indicate different $\mathrm{O}=\mathrm{U}=\mathrm{O}: \mathrm{U}-\mathrm{O}-\mathrm{U}$ ratios on the corresponding surfaces. Fig. 8 b shows a plot with the $\mathrm{O}: \mathrm{U}$ ratios $v s$. the corresponding $\mathrm{O}=\mathrm{U}=\mathrm{O}: \mathrm{U}-\mathrm{O}-\mathrm{U}$ ratios for surfaces of untreated and treated crystals of becquerelite and billietite (Table 3 ).

Inspection of the Figs. $8 \mathrm{~b}$ and 11 shows that:

(1) Surfaces treated with acidic solutions have higher $\mathrm{O}=\mathrm{U}=\mathrm{O}: \mathrm{U}-\mathrm{O}-\mathrm{U}$ and $\mathrm{O}: \mathrm{U}$ ratios than untreated surfaces;

(2) There is a correlation between the $\mathrm{O}: \mathrm{U}$ ratios and the corresponding $\mathrm{O}=\mathrm{U}=\mathrm{O}: \mathrm{U}-\mathrm{O}-\mathrm{U}$ ratios for surfaces of billietite (circles) and becquerelite (triangles); 
(3) Surfaces of untreated and treated billietite crystals have, in general, lower $\mathrm{O}: \mathrm{U}$ but higher $\mathrm{O}=\mathrm{U}=\mathrm{O}: \mathrm{U}-\mathrm{O}-\mathrm{U}$ ratios than untreated and treated surfaces of becquerelite;

(4) Billietite and becquerelite surfaces treated with $\mathrm{Na}_{2} \mathrm{CO}_{3}$ solutions (i.e. with Na-uranyl-hydroxy-hydrate precipitates) have similar $\mathrm{O}=\mathrm{U}=\mathrm{O}: \mathrm{U}-\mathrm{O}-\mathrm{U}$ and $\mathrm{O}: \mathrm{U}$ ratios (squares) and

(5) Billietite and becquerelite surfaces treated with deionized water (i.e. with schoepite-type precipitates, diamond and inverted triangle) have higher $\mathrm{O}: \mathrm{U}$ ratios than surfaces treated with acidic solutions.

Higher $\mathrm{O}$ : $\mathrm{U}$ ratios on all treated surfaces indicate a higher number of kink sites and/or $\mathrm{H}_{2} \mathrm{O}_{\text {interst }}$ species relative to an untreated surface. The correlation between the ratios $\mathrm{O}=\mathrm{U}=\mathrm{O}: \mathrm{U}-\mathrm{O}-\mathrm{U}$ and $\mathrm{O}: \mathrm{U}$ indicates that protonation of equatorial $\mathrm{O}$-atoms occurs at similar rates as formation of kink sites along steps and etch-pits. The very high $\mathrm{O}: \mathrm{U}$ ratio on surfaces treated with deionized water must be related to the precipitation of the schoepite-type phase, whereas the lower $\mathrm{O}=\mathrm{U}=\mathrm{O}: \mathrm{U}-\mathrm{O}-\mathrm{U}$ ratios on surfaces treated with a $\mathrm{Na}_{2} \mathrm{CO}_{3}$ solutions of $\mathrm{pH} 10.5$ must be a consequence of the deprotonation of equatorial $\mathrm{U}-\mathrm{OH}$ terminations in solutions of high $\mathrm{pH}$. The differences between the $\mathrm{O}=\mathrm{U}=\mathrm{O}: \mathrm{U}-\mathrm{O}-\mathrm{U}$ and $\mathrm{O}: \mathrm{U}$ ratios on the surfaces of billietite and becquerelite cannot be explained with their crystal structures because both minerals contain identical layers of polymerized uranyl-polyhedra (see above).

\subsubsection{Uranophane}

The $\mathrm{O}=\mathrm{U}=\mathrm{O}$ and $\mathrm{T}-\mathrm{O}$ bands in the $\mathrm{O} 1 s$ spectra of uranophane can be used to monitor the amount of precipitated silica or uranyl-hydroxy-hydrate. The corresponding species occur only in uranyl polyhedra or in silicate polyhedra that are linked to uranyl polyhedra. In this way, precipitation of a uranyl-hydroxy-hydrate phase on the surface of uranophane results in an increase in the mole proportion of $U$ and hence, in an increase in the proportions of $\mathrm{O}=\mathrm{U}=\mathrm{O}+\mathrm{T}-\mathrm{O}$ (Fig. 10c). Precipitation of amorphous silica produces a decrease in the mole proportion of $U$ and in the number of $\mathrm{Si}-\mathrm{O}-\mathrm{U}$ linkages, and results in a decrease in the proportions of $\mathrm{O}=\mathrm{U}=\mathrm{O}+\mathrm{T}-\mathrm{O}$ (Fig. 10c [15]).

\subsubsection{Zippeite}

The changes in chemical composition on the surface of zippeite treated with acidic solutions of $\mathrm{pH} 2$ can be monitored with the increase in the ratios $\mathrm{S}: \mathrm{U}$ and $\mathrm{U}: \mathrm{K}$ relative to an untreated surface. Fig. 10f shows that both ratios are higher on treated than untreated surfaces, indicating depletion of $\mathrm{K}$ and $\mathrm{U}$ relative to $\mathrm{U}$ and $\mathrm{S}$, respectively.

The depletion of $\mathrm{U} v s$. S indicates precipitation of phases with a higher stoichiometric ratios of $\mathrm{S}$ : $\mathrm{U}$ than zippeite.

The depletion of K vs. U can be explained by two different mechanisms:

1. $\mathrm{K}$ is replaced in the upper surface layers by the hydronium ion $\left(\mathrm{H}_{3} \mathrm{O}\right)^{+}$, resulting in a zippeite surface depleted in $\mathrm{K}$;

2. $\left(\mathrm{UO}_{2}\right)^{2+}, \mathrm{K}$ and $\left(\mathrm{SO}_{4}\right)^{2-}$ are released from the mineral surface during dissolution and subsequent precipitation of uranyl-hydroxy-hydrates or $\left(\mathrm{UO}_{2}\right)^{2+}$-bearing sulfates result in an enrichment of $\mathrm{U} v s$. $\mathrm{K}$.

Fig. 10f indicates with a solid line the $1: 1$ ratio between the increases in ratios of $\mathrm{S}: \mathrm{U}$ and $\mathrm{U}: \mathrm{K}$. It is apparent that both ratios increase nearly linear on surfaces treated with acidic solutions, which indicates that the precipitation of sulfatebearing phases (increase in $\mathrm{S}: \mathrm{U}$ ) is coupled with either the loss of $\mathrm{K}$ during dissolution or the amount of co-precipitated $\left(\mathrm{UO}_{2}\right)^{2+}$ (see above).

\subsubsection{Conclusions on coupled dissolution/precipitation reactions and effects on dissolution processes}

Coupled dissolution-precipitation reactions are common on the surface of uranyl-minerals and produce coatings with a thickness most commonly on the nanometer scale. The occurrence of coatings depends on the $\mathrm{pH}$, the type of cation in solution, and the type of oxy-anion in the structure of the uranyl mineral. The replacement of metaschoepite by a clarkeite-type phase resulted in a decrease of the dissolved U-species in solution [53], suggesting that U-bearing coatings on the surface of uranyl minerals also change the amount of dissolved U-species in equilibrium with mineral and solution.

\subsection{Overall discussion}

The experiments outlined above involved the examination of dissolution features under strong acidic conditions ( $\mathrm{pH}$ 2) and dissolution-precipitation processes at $\mathrm{pH} 3.5$ and under neutral and basic conditions. The results of these experiments can be now used to predict potential reactions on the interface between uranyl-bearing phases and pore waters of different $\mathrm{pH}$.

\subsubsection{Acidic conditions}

Solutions of low $\mathrm{pH}$ are common in acid mine tailings through generation of sulfuric acid via oxidation of sulfide minerals such as pyrite, $\mathrm{FeS}_{2}$, and pyrrohotite, $\mathrm{Fe}_{x} \mathrm{~S}$. Interaction of initially formed uranyl minerals with acidic solutions results in the formation of etch pits on the surface of all uranyl minerals and, in the case of zippeite and uranophane, in the formation of surface precipitations enriched in $\mathrm{S}$ and $\mathrm{Si}$, respectively. The observed changes in relief and morphology of etch pits indicate that dissolution processes on uranyl minerals depend strongly on the degree of undersaturation of the ambient aqueous solution and the type of cation in solution. Furthermore, dissolution experiments involving becquerelite, billietite, fourmarierite and uranophane [11-15] showed that the type of cation in solution also affects the dissolution rate of a uranyl mineral under acidic conditions. Schindler et al. [11-15] explained this phenomenon via the stability of different adsorption complexes between surface terminations (Lewis bases) and cationic aqueous species (Lewis acids). The dissolution studies on single crystals and powder samples of uranophane [15] showed that the thickness of the amorphous silica layer increases with increasing dissolution rate of the mineral, indicating that the latter coating does not inhibit the dissolution process on the surface of uranophane. 
Conversely, the formation of an almost continuous coating of $\mathrm{Ba}_{1.2}\left(\mathrm{UO}_{2}\right)_{0.8}\left(\mathrm{SO}_{4}\right)_{2}$ on the surface of zippeite suggests that sulfate-bearing coatings can alter the solubility of the mineral with respect to sulfate-bearing solutions of low $\mathrm{pH}$.

\subsubsection{Neutral and basic conditions}

In contaminated soils, dissolution and subsequent formation of thin coatings of uranyl minerals may be the dominant surface process involving uranyl-minerals or uranyl-bearing phases and pore waters of $\mathrm{pH} 5$ to 8 (the typical $\mathrm{pH}$ range for natural solutions). For example, Stubbs et al. [2] identified metatorbernite, $\mathrm{Cu}\left(\mathrm{H}_{2} \mathrm{O}\right)\left[\left(\mathrm{UO}_{2}\right)_{2}\left(\mathrm{PO}_{4}\right)_{2}\right]$, and five other hosts for $\mathrm{U}^{6+}$ in contaminated sediments at the Hanford site. The above results suggest that interactions of these hosts with the local pore water ( $\mathrm{pH} 7.2$, Um et al. [60]) result in the formation of nanometer-thick coatings of uranyl minerals on the surface of each host. The above experiments further indicated that the type of uranyl mineral in the coating varies primarily with the $\mathrm{pH}$ and composition of the ambient solution, suggesting that the type of host material has little effect on the type of uranyl-mineral present in the surface coating.

\section{Conclusions and future work}

AFM examination of dissolution features on the uranylminerals, curite, becquerelite, billietite, fourmarierite, Nabearing metaschoepite, uranophane and zippeite indicate that

1. The stability of edges on the basal surfaces of uranyl minerals is controlled by the $\mathrm{pH}$ of the ambient solution and the type of cation in solution;

2. The change in relief of etch pits on the basal surface increases with the degree of undersaturation.

3. AFM and XPS examination of surfaces of uranyl minerals treated with solutions of different $\mathrm{pH}$ and composition showed that many of the treated surfaces were covered by nano- to micrometer-thick coatings. These observations suggest that similar coatings may occur on the surface of weathered uranyl minerals or uranyl-bearing phases, armoring the underlying mineral from further dissolution.

\subsection{Directions for future work}

Modeling the fate or uranium and other radionuclides in the environment requires knowledge of

1. The solubility constants of their hosts;

2. The dissolution rates of their hosts;

3. The formation of mineral coatings on the surface of their hosts;

4. The rate of mineral replacement reactions associated with their hosts.

The latter three points are not yet well understood and the results of this and other studies $[15,53]$, indicate that $\mathrm{pH}$ and the type of cation in solution have a prominant effect on dissolution rates, formation of mineral coatings and rates of mineral-replacement reactions. Future studies on single crystals and powder samples of uranyl minerals should focus on
1. The effect of the type of cation in solution on the dissolution rate of uranyl minerals in the $\mathrm{pH}$ range of natural solutions ( $\mathrm{pH} 5-8)$;

2. TEM studies of cross-sections of mineral coatings either formed on uranyl minerals in contaminated soils and mine tailings or on uranyl minerals during dissolution experiments in order to identify the minerals (and amorphous phases) present in the coating.

Acknowledgment. This work was supported by a Canada Research Chair in Crystallography and Mineralogy to FCH, by Discovery Grants to MS and FCH from the Natural Sciences and Engineering Research Council of Canada, and by a CFI grant for surface science at the University of Manitoba. PCB and PAM were supported by the National Science Foundation Environmental Molecular Science Institute at the University of Notre Dame (EAR02-21966). We thank Associate Editor Sue Clark and two anonymous reviewers for their comments on an earlier version of the manuscript.

\section{References}

1. Finch, R. J., Ewing, R. C.: The corrosion of uraninite under oxidizing conditions. J. Nucl. Mater. 190, 133 (1992)

2. Stubbs, J. E., Veblen, L. A., Elbert, D. C., Zachara, J. M., Davis, J. A., Veblen, D. R.: Newly recognized hosts for uranium in the Hanford Site vadose zone. Geochim. Cosmochim. Acta 73, 1563 (2009).

3. McKinley, J. P., Zachara, J. M., Liu, C., Heald, S. M., Prenitzer, B. I., Kempshall, B.W.: Microscale controls on the fate of contaminant uranium in the vadose zone, Hanford Site, Washington. Geochim. Cosmochim. Acta 70, 1873 (2006).

4. Wang, Z., Zachara, J. M., Gassman, P. L., Liu, C., Qafoku, O., Yantasee, W., Catalano, J. G.: Fluorescence spectroscopy of U(VI)-silicates and U(VI)-contaminated Hanford sediment. Geochim. Cosmochim. Acta 69, 1391 (2005).

5. Buck, E. C., Brown, N. R., Dietz, N. L.: Contaminant uranium phases and leaching at the Fernald site in Ohio. Environ. Sci. Technol. 30, 81 (1996).

6. Brugger, J., Burns, P. C., Meisser, N.: Contribution to the mineralogy of acid drainage of uranium minerals: Marecottite and the zippeite-group. Am. Mineral. 88, 676 (2003).

7. Schindler, M., Mutter, A., Hawthorne, F. C., Putnis, A.: Prediction of crystal morphology of complex uranyl-sheet minerals: I. Theory. Can. Mineral. 42, 1629 (2004).

8. Schindler, M., Mutter, A., Hawthorne, F. C., Putnis, A.: Prediction of crystal morphology of complex uranyl-sheet minerals: II. Observation. Can. Mineral. 42, 1651 (2004).

9. Schindler, M., Putnis, A.: Crystal growth of schoepite on the (104) surface of calcite. Can. Mineral. 42, 1629 (2004).

10. Schindler, M., Hawthorne, F. C., Putnis, C., Putnis, A.: Growth of uranyl-hydroxy-hydrate and uranyl-carbonate minerals on the (104) calcite surface. Can. Mineral. 42, 1683 (2004).

11. Schindler, M, Mandaliev, P., Hawthorne, F. C., Putnis, A.: Dissolution of uranyl-hydroxy-hydrate mineraIs: I. Curite. Can. Mineral. 44, 415 (2006).

12. Schindler, M., Hawthorne, F. C., Burns, P. C., Maurice, P. A.: Dissolution of uranyl-hydroxy-hydrate minerals: II. Becquerelite. Can. Mineral. 44, 1207 (2006).

13. Schindler, M, Hawthorne, F. C., Halden, N. M., Burns, P. C., Maurice, P. A.: Dissolution of uranyl-hydroxy-hydrate minerals: III. Billietite. Can. Mineral. 45, 945 (2007).

14. Schindler, M., Hawthorne, F. C., Burns, P. C., Maurice, P. A.: Dissolution of uranyl-oxide-hydroxy-hydrate minerals. IV. Fourmarierite and synthetic $\mathrm{Pb}_{2}\left(\mathrm{H}_{2} \mathrm{O}\right)\left[\left(\mathrm{UO}_{2}\right)_{10} \mathrm{UO}_{12}(\mathrm{OH})_{6}\left(\mathrm{H}_{2} \mathrm{O}\right)_{2}\right]$. Can. Mineral. 45, 963 (2007).

15. Schindler, M., Freund, M., Hawthorne, F. C., Burns, P. C., Maurice, P. A.: Dissolution of uranophane: an AFM, XPS and SEM study. Geochim. Cosmochim. Acta 73, 2510 (2009).

16. Finch, R. J., Murakami, T.: Systematics and paragenesis of uranium minerals. Rev. Mineral. 38, 91 (1999). 
17. Burns, P. C., Deely, K. M., Hayden, L. A.: The crystal chemistry of the zippeite group. Can. Mineral. 41, 687 (2003).

18. Klingensmith, A. L., Burns, P. C.: Neptunium substation in synthetic uranophane and soddyite. Am. Mineral. 92, 1946 (2007).

19. Burns, P. C., Li, Y.: The structures of becquerelite and $\mathrm{Sr}-$ exchanged becquerelite. Am. Mineral. 87, 550 (2002).

20. Klingensmith, A. L., Deely, K. M., Kinman, W. S., Kelly, V., Burns, P. C.: Neptunium incorporation in sodium-substituted metaschoepite. Am. Mineral. 92, 662 (2007).

21. Pouchou, J. L., Pichoir, F.: "PAP" $\phi(\mathrm{rZ})$ procedure for improved quantitative microanalysis. In: Microbeam Analysis. San Francisco Press, San Francisco (1985).

22. Langmuir, D.: Uranium solution-mineral equilibria at low temperatures with applications to sedimentary ore deposits. Geochim. Cosmochim. Acta 42, 547 (1978).

23. Becker, U., Biswas, S., Kendall, T., Risthaus, P., Putnis, C. V., Pina, C. M.: Interactions between mineral surfaces and dissolved species: From monovalent ions to complex organic molecules. Am. J. Sci. 305, 791 (2005).

24. Robinson, R. A., Stokes, R. H.: Electrolyte Solutions, the Measurement and Interpretation of Conductance, Chemical Potential, and Diffusion in Solutions of Simple Electrolytes. $2^{\text {nd }}$ Edn., Butterworths, London (1968).

25. Gustafsson, J. P.: Visual MINTEQ, Version 2.53. KTH, Department of Land and Water Resources Engineering, Stockholm (1997).

26. Grenthe, I., Plyasunov, A., Spahiu, K.: Estimations of medium effects on thermodynamic data. In: Modelling in Aquatic Chemistry. (Grenthe, I., Puigdomenech, I., eds.) OECD Nuclear Energy Agency, Paris (1997).

27. Schindler, M., Freund, M., Hawthorne, F. C., Burns, P. C.: XPS spectra of uranyl minerals and synthetics. I. The U $4 f$ spectrum. Geochim. Cosmochim. 73, 2471 (2009).

28. Schindler, M., Freund, M., Hawthorne, F. C., Burns, P. C.: XPS spectra of uranyl minerals and synthetics. II. The O $1 s$ spectrum. Geochim. Cosmochim. 73, 2488 (2009).

29. Shirley, D. A.: High-resolution X-ray photoemission spectrum of the valence bands of gold. Phys. Rev. B 5, 4709 (1972).

30. Wagner, C. D., Riggs, W. M., Davis, L. E., Moulder, J. F., Mailenberg, G. M.: Handbook of X-ray photoelectron spectroscopy. Perkin-Elmer, Eden Prairie (1979).

31. Vision 2.2.6: Kratos Analytical Ltd, Manchester (2006).

32. Lasaga, A. C., Lüttge, A.: Variation of crystal dissolution rate based on a dissolution stepwave model. Science 291, 2400 (2001).

33. Lasaga, A. C., Lüttge, A.: A model for crystal dissolution. Eur. J. Mineral. 15, 603 (2003).

34. Arvidson, R. S., Beig, M. S., Lüttge, A.: Single-crystal plagioclase feldspar dissolution rates measured by vertical scanning interferometry. Am. Mineral. 89, 51 (2004).

35. Frank, F. C.: Capillary equilibria of dislocated crystals. Acta Crystallogr. 4, 497 (1951).

36. Carbera, N., Levine, M. M., Plaskett, J. S.: Hollow dislocations and etch pits. Phys. Rev. 96, 1153 (1954).

37. Lasaga, A. C.: Kinetics of silicate dissolution. In $4^{\text {th }}$ International Symposium on Water-Rock Interactions, Misasa, Japan (1983).

38. Teng, H. H.: Controls by saturation state on etch pit formation during calcite dissolution. Geochim. Cosmochim. Acta 68, 253 (2004).

39. Burton, W. K., Carbera, N., Frank, F. C.: The growth of crystals and the equilibrium structure of their surfaces. Phil. Trans. R. Soc. Lond. A 243, 299 (1951).
40. Noe, D. C., Veblen, D. R.: HRTEM analysis of dislocation cores and stacking faults in naturally deformed biotite crystals. Am. Mineral. 84, 1925 (1999).

41. Pagoaga, M. K., Appleman, D. E., Stewart, J. M.: Crystal structure and crystal chemistry of the uranyl oxide hydrates becquerelite, billietite and protastite. Am. Mineral. 72, 1230 (1987).

42. Finch, R. J., Burns, P. C., Hawthorne, F. C., Ewing, R. C.: Refinement of the crystal structure of billietite, $\mathrm{Ba}\left[\left(\mathrm{UO}_{2}\right)_{6} \mathrm{O}_{4}(\mathrm{OH})_{6}\right]$ $\left(\mathrm{H}_{2} \mathrm{O}\right)_{7}$. Can. Mineral. 44, 1197 (2006).

43. Finch, R. J. Cooper, M. A., Hawthorne, F. C., Ewing, R. C.: The crystal structure of schoepite, $\left[\left(\mathrm{UO}_{2}\right)_{8} \mathrm{O}_{2}(\mathrm{OH})_{12}\right]\left(\mathrm{H}_{2} \mathrm{O}\right)_{12}$. Can. Mineral. 34, 1071 (1996).

44. Weller, M. T., Light, M. E., Gelbrich, T.: Structure of uranium(VI) oxide dehydrate, $\mathrm{UO}_{3} \cdot 2 \mathrm{H}_{2} \mathrm{O}$, synthetic metaschoepite, $\left(\mathrm{UO}_{2}\right)_{4} \mathrm{O}$ $(\mathrm{OH})_{6} \cdot 5 \mathrm{H}_{2} \mathrm{O}$. Acta Crystallogr. B 56, 577 (2000).

45. Piret, P.: Structure cristalline de la fourmarierite, $\mathrm{Pb}\left(\mathrm{UO}_{2}\right)_{4} \mathrm{O}_{3}$ $(\mathrm{OH})_{4} \cdot 4 \mathrm{H}_{2} \mathrm{O}$. Bull. Mineral. 108, 659 (1985).

46. Li, Y., Burns, P. C.: Investigations of crystal-chemical variability in lead uranyl oxide hydrates. III. Fourmarierite. Can. Mineral. 38, 737 (2000).

47. Smith, D. K.: Uranium mineralogy. In: Uranium Geochemistry, Mineralogy, Geology, Exploration and Resources. (Ippolito, F., de Vero, B., Copaldi, G., eds.) Institution of Mining and Metallurgy, London (1984).

48. Vochten, R., Van Haverbeke, L., Van Springel, K., Blaton, N., Peeters, O. M.: The structure and physicochemical characteristics of synthetic zippeite. Can. Mineral. 33, 1091 (1995).

49. Nguent, M. A., Brantley, S. L., Pantano, C. G., Maurice, P. A.: The influence of natural mineral coatings on feldspar weathering. Nature 395, 588 (1998).

50. Zhu, C., Veblen, D. R., Blum, A. E., Chipera, S. J.: Naturally weathered feldspar surfaces in the Navajo Sandstone aquifer, black Mesa, Arizona: Electron microscopic characterization. Geochim. Comsmochim. Acta 70, 4600 (2006).

51. Finch, R. J., Ewing, R. C.: Clarkeite, new chemical and structural data. Am. Mineral. 82, 607 (1997).

52. Li, Y., Burns, P. C.: The structures of two sodium uranyl compounds relevant to nuclear waste disposal. J. Nucl. Mater. 299, 219 (2001).

53. Giammer, D. B., Hering, J. G.: Influence of dissolved sodium and cesium on uranyl oxide hydrate solubility. Environ. Sci. Technol. 38, 171 (2004).

54. Yamamura, T., Kitamura, A., Fukui, A. Nishikawa, S., Yamamoto, T., Moriyama, H.: Solubility of U(VI) in highly basic solutions. Radiochim. Acta 83, 139 (1998).

55. Ondrus, P., Skala, R., Veselovsky, F., Sejkora, J., Vitti, C.: Cejkaite, the triclinic polymorph of $\mathrm{Na}_{4}\left(\mathrm{UO}_{2}\right)\left(\mathrm{CO}_{3}\right)_{3}$ - a new mineral from Jachymov. Czech Republic. Am. Mineral. 88, 686 (2003).

56. Li, Y., Krivovichev, S. V., Burns, P. C.: The crystal structure of $\mathrm{Na}_{4} \mathrm{UO}_{2}\left(\mathrm{CO}_{3}\right)_{3}$ and its relationship to schröckingerite. Mineral. Mag. 65, 297 (2001).

57. Li, Y., Burns, P. C.: The crystal structure of synthetic grimselite, $\mathrm{K}_{3} \mathrm{Na}\left[\left(\mathrm{UO}_{2}\right)\left(\mathrm{CO}_{3}\right)_{2}\right]\left(\mathrm{H}_{2} \mathrm{O}\right)$. Can. Mineral. 39, 1147 (2001).

58. Mereiter, K.: Crystal structure and crystallographic properties of a schröckingerite from Joachimsthal. TMPM Tschermaks Mineral. Petrogr. Mitt. 35, 1-18 (1986).

59. Casey, W. H., Westrich, H. R., Arnold, G. W., Banfield, J. F.: The surface chemistry of labradorite feldspar. Geochim. Cosmochim. 53, 821 (1989).

60. Um, W., Serne, R. J., Brown, C. F., Rod, K. A.: Uranium(VI) sorption on iron oxides in Hanford Site sediment: application of a surface complexation model. Appl. Geochem. 23, 2649 (2008). 